\title{
En busca de la prevalencia perdida
}

\author{
Manuel Rebollo Puig \\ Catedrático de Derecho Administrativo. \\ Universidad de Córdoba ${ }^{1}$
}

SUMARIO: I. PLANTEAMIENTO: EL TRISTE DESTINO DE LA PREVALENCIA Y LA USURPACIÓN DE SU TERRENO POR LA COMPETENCIA. II. ¿POR QUÉ DAR PREVALENCIA AL DERECHO ESTATAL? III. PREVALENCIA Y SUPERIORIDAD. IV. COMPETENCIA Y PREVALENCIA. V. LA PREVALENCIA COMO REGLA DE RESOLUCIÓN DE CONFLICTOS NORMATIVOS Y COMO LÍMITE MATERIAL AL EJERCICIO DE LAS COMPETENCIAS AUTONÓMICAS. VI. ¿QUÉ NORMAS ESTATALES PREVALEGEN SOBRE QUÉ NORMAS AUTONÓMICAS? VII. CONSECUENCIAS DE LA PREVALENCIA EN CASOS DE CONFLICTO ¿DESPLAZAMIENTO O NULIDAD DE LA NORMA AUTONÓMICA? VIII. ¿QUIÉN APLICA LA PREVALENCIA DE LAS NORMAS ESTATALES? IX. RECAPITULACIÓN Y PROPUESTA. X. ADENDA. LA REGTIFICACIÓN PARGIAL DEL TRIBUNAL CONSTITUCIONAL EN SUS SENTENCIAS 102, 116 y 127/2016

\section{RESUMEN}

El principio de prevalencia del Derecho estatal sobre el Derecho autonómico ha sido mínimamente utilizado por el Tribunal Constitucional que ha desperdiciado todas sus posibilidades. Ello ha tenido lamentables consecuencias. Las peores se han manifestado en la jurisprudencia constitucional reciente, de la que es acabado ejemplo la STC 66/2011, que merma gravemente la capacidad del legislador estatal para imponer efectivamente reformas. Frente a ello, aquí se destaca la necesidad, fundamento e importancia del principio de prevalencia. Se sostiene que urge restablecerlo en toda su dimensión y operatividad. Asimismo, se precisa su función, alcance y efectos según la clase de conflictos que se presenten.

\footnotetext{
${ }^{1}$ Grupo de Investigación de la Junta de Andalucía SEJ-196. Proyecto DER2015-67695-C2-1-P(MINECO/FEDER, UE). Este artículo tiene su origen en la aportación al homenaje al Profesor Santiago Muñoz Machado pero se han introducido cambios e incorporado novedades posteriores.
} 


\section{PLABRAS CLAVE:}

Estado autonómico. Relaciones entre ordenamientos. Competencia y prevalencia. Funciones del Tribunal Constitucional y de los Jueces, Tribunales y demás operadores jurídicos.

\section{ABSTRACT}

The Spanish Constitutional Court has barely applied the principle of the State law taking precedence over the Law of the Autonomous Communities. Therefore, the High Court has missed out the potential of this principle. This behaviour has had unfortunate consequences, which are to be seen in the most recent constitutional case law, whose best example is the Judgment 66/2011. This Judgment limits the capacity of the Legislative power to efectively impose reforms. In this paper the author states the need and significance of the principle of the State law taking precedence over autonomous law, as well as its legal foundation. He also argues that this principle should be re-established in its whole dimension and effectivity. Finally, the author analyses the function, scope and effects of the aforementioned principle according to the type of conflict it tries to solve.

KEY WORDS: Autonomous Communities State. Relations between legal orders. Competence and precedence. Functions of the Spansh Constitutional Court, the Judges, the Courts and the authorities.

\section{PLANTEAMIENTO: EL TRISTE DESTINO DE LA PREVA- LENCIA Y LA USURPACIÓN DE SU TERRENO POR LA COMPETENCIA}

El Tribunal Constitucional ha invocado poco el principio de prevalencia del Derecho estatal que proclama el art. 149.3 CE. No es sólo que lo nombre escasamente; es que lo aplica aun menos. Y no por simple olvido: su jurisprudencia, en conjunto, lo arrumba y desactiva. Un voto particular magistral del Magistrado Delgado Barrio a la STC 66/2011 se refiere al "triste destino" que la doctrina del TC ha asignado a la prevalencia del Derecho estatal "de la que este Tribunal viene prescindiendo reiteradamente". De una u otra forma, así se suele reconocer². Y, en efecto, con permiso de

${ }^{2}$ En la doctrina, vid. MUÑOZ MACHADO, S., Informe sobre España. Repensar el Estado o destruirlo, Crítica, Barcelona, 2012, p. 136, dice que la jurisprudencia del TC "ha conducido a minimizar el valor de la cláusula de prevalencia”. En la misma línea RUÍZ LÓPEZ, M. A., "La cláusula de prevalencia del Derecho estatal y la colisión entre jurisdicciones", RAP, n 192 (2013), pp. 142 y 151-152, hasta afirmar que la prevalencia "no existe, es invisible a los ojos del Tribunal Constitucional". FERNÁNDEZ FARRERES, G., La contribución del Tribunal Constitucional al Estado Autonómico, Iustel, Madrid, 2005, p. 433, dice de la prevalencia que estamos "ante un precepto constitucional prácticamente vacío de contenido". Igualmente COSCULLUELA 
Delgado Barrio y de Isabel II, podemos apodar a la prevalencia como "la de los tristes destinos".

Esa marginación, sin embargo, ni está justificada ni es inocua sino errónea y perturbadora; se aparta de lo establecido en la Constitución, enturbia las instituciones, socava al sistema, dificulta su funcionamiento y debilita al Estado más allá de todo límite razonable. No hay exageración en esta afirmación y, si alguna duda cupiera, la última jurisprudencia del TC, secuela de su abandono del principio de prevalencia, ha hecho más patentes los corrosivos efectos que ya contenía en germen su doctrina anterior. Urge, pues, repensar todo lo que puede y debe significar la prevalencia del Derecho estatal para rectificar desde su raíz una doctrina constitucional tan infundada como demoledora. Hacerlo para recuperar lo que debe ser una pieza clave del sistema establecido por la Constitución como lo es en Estados federales clásicos ${ }^{3}$ y en la misma Unión Europea ${ }^{4}$. A eso dedicaremos estas páginas. La tarea no es sencilla: no tanto por las dificultades intrínsecas del principio sino porque se necesitan ahora muchas explicaciones para desmontar todas las ideas erróneas y complicadas que se han ido extendiendo y que lo han ido erosionando.

Dato fundamental es la correlativa hipertrofia del principio de competencia. Se suele señalar que el ordenamiento estatal y los autonómicos se articulan entre sí conforme a dos principios, el de competencia y el de prevalencia. Pues bien, la postergación del principio de prevalencia ha venido acompañada de la inflación desmesurada del de competencia. No sabría decir qué es causa y qué efecto ¿se ha relegado la prevalencia por haberle dado al principio de competencia una función desorbitada o el principio de competencia se ha visto obligado a ocupar todo lo que previamente se negó

MONTANER, L., "El control de las leyes autonómicas reguladoras de materias cuya regulación básica corresponde al Estado”, en La protección jurídica del ciudadano. Estudios en homenaje del Profesor Jesús González Pérez, Civitas, Madrid, 1993, III, pp. 1573-1574"; y SOSA WAGNER, F., "Para el debate entre colegas sobre la reconstrucción del Estado Autonómico", El Cronista del Estado social y democrático de Derecho, n ${ }^{\circ} 51$ (2015), p. 37. Además de Delgado Barrio, otros Magistrados del TG han criticado en votos particulares el olvido de la prevalencia. Es expresivo y sugerente el de Rodríguez-Zapata a la STC 247/2007.

${ }^{3}$ DE OTTO y PARDO, I., dedicó en buena parte su estudio "La prevalencia del Derecho estatal sobre el Derecho regional", $R E D C, \mathrm{n}^{\circ} 2$ (1981), pp. 57 y ss., a demostrar que no se podía trasladar aquella construcción de muchos Estados federales -no de todos- a nuestro Estado autonómico. Pero todos los presupuestos en los que se basaba han quedado superados y no hay ningún inconveniente, sino todo lo contrario, para que esa clave de bóveda de los Estados federales valga también para nuestro Estado autonómico.

${ }^{4}$ A este respecto no puede dejar de sorprender la paradoja que entraña que, sin que ningún Tratado lo proclamase, rige con inusitada potencia la primacía del Derecho de la Unión Europea, y que, por el contrario, en España, con expresa consagración constitucional de la prevalencia, haya quedado relegada al ostracismo. Que en el primer caso un Tribunal creativo y consciente de su misión lo construyera y que en el segundo otro Tribunal que contaba con una consagración constitucional lo haya destruido. 
a aquélla? ¿qué fue antes, el huevo o la gallina? Lo cierto es que son fenómenos inescindibles, que todo el lugar que ahora no cubre la prevalencia lo ha invadido el principio de competencia o, si se prefiere, que la expansión de éste ha dejado sin espacio a la prevalencia. Así, en la jurisprudencia del TC y en gran parte de la doctrina española se ha tendido a resolver como problemas de competencia todas las situaciones conflictivas que tenían su respuesta natural -y la prevista y querida por la Constituciónen el principio de prevalencia.

No se piense que es irrelevante usar uno u otro principio, que todo funciona igual de bien (o igual de mal) y se llega a lo mismo resolviendo los problemas conforme a la competencia o conforme a la prevalencia. Nada más lejos de la verdad. Todo funciona peor que si cada uno de esos principios cumpliera su función, toda su función, pero sólo su respectiva función.

El enseñoramiento por el principio de competencia de lo que debería ser propio de la prevalencia ha arrastrado oscuridad y la deformación de casi todo. En síntesis, ha llevado a una interpretación obtusa del mismo sistema de distribución de competencias para permitirle, más mal que bien, cumplir funciones que no son las suyas. Así, para paliar los efectos más demoledores del olvido del principio de prevalencia que se observan a veces, se han hecho en ocasiones interpretaciones muy restrictivas e incomprensibles de las competencias autonómicas; se ha afirmado que muchas leyes estatales (sobre todo, las leyes básicas) delimitan competencias, en vez de afirmar simplemente que son prevalentes; se ha dado contornos imprecisos y, en cualquier caso, demasiado amplios al concepto de bloque de la constitucionalidad; se ha desorbitado el vicio de incompetencia para incluir en él vicios materiales o de contenido (vulneración de las normas prevalentes); etc. Acaso entre las perversiones que causa la sobrecarga del principio de competencia merezca crítica especial el abuso de la noción de títulos competenciales prevalentes: en vez de decir que dos normas, una estatal y otra autonómica, se han dictado dentro de sus respectivos ámbitos de competencias pero que aquélla prevalece sobre ésta, el TC tiende a violentar la idea de que un título competencial prevalece sobre otro y que, consiguientemente, una de las normas se dictó con incompetencia, lo cual, además de resultar en muchos casos retorcido, arroja resultados funestos y contrarios a la Constitución, precisamente contrarios a la prevalencia del Derecho estatal. Y, aun así, todo con enormes dificultades porque, por mucho que se le deforme, el principio de competencia no soporta el peso que se ha depositado sobre él. De otro lado, la relegación del principio de prevalencia ha laminado (ahora más que nunca, como se verá) la posibilidad (deber, en realidad) de inaplicar las normas autonómicas contrarias a las estatales posteriores prevalentes; exactamente al contrario de lo que sucede en la Unión Europea cuyo principio de primacía tiene su corolario en el llamado principio de inaplicación de las normas nacionales (todas, hasta las Cons- 
tituciones) contrarias al Derecho de comunitario (todo él, anterior o posterior, incluyendo sus actos no normativos). En su lugar, se han establecido en España mecanismos más rígidos y más torpes apoyados, para más inri, en conceptos inasumibles; en el fondo, incluso, aunque no se utilice literalmente esta expresión, en el de incompetencia sobrevenida, que es un monstruo contra la razón. A todo ello súmese que la estrategia de descargar todo sobre el principio de competencia es especialmente desafortunada en nuestro sistema que, como es notorio y por decirlo benévolamente, no tiene entre sus puntos fuertes la distribución de competencias ${ }^{5}$.

Así que no hay indiferencia entre competencia y prevalencia. Al contrario. Importa, y mucho, recuperar a ésta, rescatarla del destierro a que ha sido condenada y permitirle, en fin, que cumpla el papel de coprotagonista que le asigna la Constitución y que se le reconoce en los sistemas compuestos. Porque el triste destino de la prevalencia es el triste y oscuro destino de todo el sistema. Sin perjuicio del papel estelar del principio de competencia, que la prevalencia reconquiste su espacio propio contribuirá notablemente a racionalizar y a mejorar el sistema. Incluso estoy persuadido de que ayudaría a que la aplicación del principio de competencia fuese más fácil y comprensible.

Deparar mejor suerte a "la de los tristes destinos" exige una gran labor, desandar mucho de lo andado por caminos equivocados y falsos atajos, destruir elementos incoherentes con el conjunto y construir (o reconstruir contando sólo con vestigios cada vez más soterrados) algunas piezas. Pero aquí no podrá acometerse por completo esa tarea hercúlea. Me conformo con intentar demostrar que es necesaria y posible y aspiro sólo, como máximo, a ofrecer algunas de las piezas con las que jugar para esa construcción.

\section{II. ¿POR QUÉ DAR PREVALENGIA AL DEREGHO ESTATAL?}

Si aceptamos -como hay que aceptar porque es un hecho incontrovertible- que la distribución de competencias no puede impedir del todo los solapamientos o superposiciones y que, desde luego, el sistema español los posibilita ampliamente ${ }^{6}$, hay

\footnotetext{
${ }^{5}$ Expresivamente MUÑOZ MACHADO, S., Informe..., cit., pp. 99 y ss., intitula su estudio del sistema de distribución competencial bajo el rubro "El inextricable universo de las competencias".

${ }^{6}$ El supuesto de norma estatal y autonómica en oposición y ambas dictadas dentro de los respectivos ámbitos de competencias, en contra de lo que pareció entender Kelsen, no sólo no es imposible sino que es inevitable y hasta ordinario y frecuente. Lo es, desde luego, en nuestro sistema. Pero lo es también en cualquier otro porque las competencias, por muy bien delimitadas que estén, se entrecruzan, se interfieren, se solapan, se superponen... hasta ofrecer numerosas intersecciones. Desde luego eso se produce en caso de
} 
que establecer alguna regla complementaria que resuelva los conflictos consecuentes. Teóricamente son posibles muchas soluciones, incluso algunas que prescindan de las cualidades de los sujetos y atiendan sólo al contenido (por ejemplo, lo especial prevalece sobre lo general). Pero lo común es establecer un criterio en función de la cualidad de los entes a los que corresponde cada ordenamiento. O sea, en nuestro caso, resolver en favor del ente más amplio que abraza a los otros o en favor de éstos. También esto último sería posible y, de hecho, se dio en momentos lejanos.

¿Por qué resolverlos en favor del Derecho estatal? La respuesta elemental a esta pregunta está en la Constitución: hay que dar prevalencia al Derecho estatal sobre los autonómicos porque lo dice la Constitución en su art. 149.3. Se podrá discutir su ámbito, su alcance... pero no la prevalencia misma. Respuesta elemental, pero nada superflua y suficiente. Respuesta que, si se está de acuerdo en el valor de la Constitución, debería bastar, por lo pronto, para desterrar algunas objeciones doctrinales, aunque invoquen el reverenciado nombre de Kelsen que, en una de sus ocurrencias menos lúcidas, creyó que la prevalencia del Derecho federal era incompatible con el respeto al sistema constitucional de distribución de competencias y que éste, respaldado por un Tribunal Constitucional, era suficiente para resolver todas las controversias ${ }^{7}$. Ya veremos que de ninguna forma es así. Ahora sólo hay que decir que si la misma Constitución proclama esta prevalencia es que nuestra Constitución no sólo no asume sino que repudia esa tesis kelseniana de que todo puede y debe resolverse exclusivamente conforme al principio de competencia. No sé lo que deba ocurrir en Austria donde, por influencia de Kelsen, su Constitución de 1920 no recogió la prevalencia. Pero el art. 149.3 CE sienta una premisa distinta e incuestionable. Lo cierto, sin embargo, es que en nuestro TC parece revivir el espíritu de Kelsen, no sólo por prescindir del principio de prevalencia, sino por hacerlo merced a una desorbitada aplicación del de competencia $^{8}$.

competencias compartidas y concurrentes sobre una misma materia. Pero se produce también indefectible e ineludiblemente entre competencias exclusivas sobre distintas materias. Es más, se produce también entre normas dictadas en materias compartidas y normas dictadas en materias exclusivas; por ejemplo, entre una norma estatal sobre medio ambiente (materia compartida) y una norma autonómica sobre urbanismo (materia de exclusiva competencia autonómica).

${ }^{7}$ Sobre esta construcción kelseniana y sus continuadores (Imboden y más tímidamente algunos autores alemanes), vid. MUÑOZ MACHADO, S., Derecho público de las Comunidades Autónomas, Iustel, $2^{\mathrm{a}}$ ed., 2007, I, pp. 519 a 525, así como DE OTTO y PARDO, I., "La prevalencia del Derecho estatal sobre el Derecho regional", cit., pp. 59 a 62, que en parte la hace suya.

${ }^{8}$ Es lo que afirma precisamente MUÑOZ MACHADO, S., Informe..., p. 136: "El modelo austríaco kelseniano ha sido utilizado preferentemente por nuestra jurisprudencia constitucional, lo que ha conducido a minimizar el valor de la cláusula de prevalencia y a configurar como conflictos de competencias todos los supuestos en los que la legislación autonómica contradice lo establecido en la ley estatal”. 
Pero si buscamos algún fundamento más a la prevalencia, algo más profundo que su pura consagración en la CE, digamos que está en la unidad de España (art. 2 CE) $)^{9}$ y en su soberanía; en que el todo es superior a las partes, en que el interés del todo es superior al de las partes, en que lo que deciden todos es superior a lo que deciden sólo algunos, lo que, a su vez, es exigencia del un sistema democrático. Porque la prevalencia del Derecho estatal en un sistema democrático no supone imposición de una decisión ajena sino de la tomada por los mismos ciudadanos con más ciudadanos. Es, al mismo tiempo, una exigencia funcional indeclinable: "En toda organización la estructura o sistema general es prevalente sobre la de todos y cada uno de los subsistemas que en su seno incluye. No es una cuestión dogmática o ideológica, sino una necesidad funcional en tanto la organización general subsista", una pieza imprescindible para la "unidad global del sistema y su cohesión última...", para "asegurar la integración final del sistema en un orden final único"10.

\section{PREVALENGIA Y SUPERIORIDAD}

Cabría decir también que la prevalencia se fundamenta en la superioridad del Derecho estatal sobre los autonómicos. El ordenamiento estatal y los autonómicos no forman "pirámides normativas paralelas ... situadas en nivel de igualdad", sino que aquél está "en un nivel superior"; "no es siquiera un primus inter pares" sino que "se encuentra en una posición de supremacía natural ... en la medida en que aquél expresa la soberanía indivisible del pueblo español” y es el "armazón unitario que permite que los subsistemas autónomos existan como tales" ${ }^{\prime 1}$. Superioridad no jerárquica, puesto que no hay propiamente tal jerarquía entre dos ordenamientos ${ }^{12}$, pero superidad a fin de cuentas: "viene a cumplir una función semejante a la que el principio de jerarquía

\footnotetext{
${ }^{9}$ MUÑOZ MACHADO, S., Derecho público de..., cit., I, pp. 240-241 y 247 a 249. Vid. también en similar dirección TEJEDOR BIELSA, J. C., La garantía constitucional de la unidad del ordenamiento en el Estado autonómico: competencia, prevalencia y supletoriedad, Civitas, 2000, pp. 206 y ss.

${ }^{10}$ GARCÍA DE ENTERRÍA, E., y FERNÁNDEZ, T. R., Curso de Derecho Administrativo, Civitas, Madrid, I, $16^{\text {a }}$ ed., 2013, pp. 388-389.

${ }^{11}$ SANTAMARÍA PASTOR, J. A., Fundamentos de Derecho Administrativo, Centro de Estudios Ramón Areces, Madrid, 1988, pp. 328-329.

${ }^{12}$ Así se afirma normalmente. Vid COSCULLUELA MONTANER, L. Manual de Derecho Administrativo, Civitas, Madrid, 25ª ed, 2014, pp. 53-54 y 118: "no juega el principio de jerarquía entre normas de distinto ordenamiento”. Y GARCÍA DE ENTERRÍA, E., y FERNÁNDEZ, T. R., Curso..., cit., I, p. 387, de acuerdo con ese postulado, niegan que la prevalencia del Derecho estatal le convierta es superior jerárquico del autonómico. Así mismo, por ejemplo, RUÍZ LÓPEZ, M. A., "La cláusula de prevalencia del Derecho estatal...", p. 150, niega la jerarquía entre normas estatales y autonómicas.

Pero no parece que sea un dogma aceptado pacíficamente en todos sitios. Por ejemplo, en Estados Unidos no se repudia la idea de una superioridad jerárquica de las normas de la federación sobre la de los
} 
juega dentro de cada sistema o subsistema"13. En realidad, me parece, sin embargo, que no es tanto que la prevalencia del Derecho estatal se sustente en su superioridad como que pone de manifiesto esa superioridad; que bien podría afirmarse como un principio en sí mismo la superioridad del Derecho estatal sobre los autonómicos, principio que tendría como efecto, entre otros, el de su prevalencia. De hecho, eso es lo que luce realmente en el art. VI, apartado 2, de la Constitución de los Estados Unidos, donde se afirma que las leyes de la federación "serán la Ley Suprema del país". Sucede, empero, que entre nosotros no se utiliza normalmente ese término de superioridad, sino sólo el de prevalencia que, por ello, tiene en el fondo dos significados: superioridad y prevalencia propiamente dicha.

Tras lo dicho, casi huelga advertir que sólo hay prevalencia del Derecho estatal sobre los autonómicos, nunca a la inversa. Es eso lo que está proclamado en el art. 149.3 $\mathrm{CE}$, lo que tiene fundamento y lo único que tiene sentido. Por el contrario, no hay en ningún caso prevalencia de los Derechos autonómicos: incluso en los casos en que la legislación autonómica sí que es capaz de desplazar a ciertas normas estatales (casos de normas estatales supletorias respecto a las autonómicas) ello se debe y se explica sólo por el principio de competencia, jamás por el de prevalencia, aunque alguna vez se haya defendido para dar así a éste un aspecto de simetría y equilibrio que es absurdo.

\section{GOMPETENGIA Y PREVALENGIA}

En contra de la tesis de origen kelseniano según la cual el principio de la prevalencia afecta a las competencias y mina o hasta dinamita la distribución establecida en la Constitución (o en el bloque de la constitucionalidad), importa destacar que de ninguna forma es así, que competencia y prevalencia tienen ámbitos y funciones diferentes. La idea puede descomponerse en otras tres para no dejar espacio alguno a equívocos. Veámoslas.

\subsection{El principio de prevalencia no decide la competencia}

La regla de la prevalencia no sirve jamás y de ninguna forma para delimitar las

Estados y, a fin de cuentas, el art. VI.2 de su Constitución califica a la ley federal de "Ley Suprema". Vid. GARCÍA LUENGO, J., "El desplazamiento de la normativa autonómica por la legislación estatal básica", en Por el Derecho y la libertad. Libro homenaje al Profesor Juan Alfonso Santamaría Pastor, Iustel, Madrid, 2014, I, p. 205. Y MUÑOZ MACHADO, S., Derecho público de las Comunidades..., cit., p. 592, no tiene empacho en afirmar que la prevalencia supone un "plusvalor" que entraña "la efectiva jerarquización de unos contenidos normativos sobre otros, de manera que no puedan resistir los inferiores el contraste...". En suma, las normas autonómicas como "inferiores" jerárquicas de las estatales.

${ }^{13}$ SANTAMARÍA PASTOR, J. A., Fundamentos..., cit., p. 329. 
competencias del Estado y de las Comunidades Autónomas. Esto hay que resolverlo en virtud de otras reglas. Esta idea se suele expresar afirmando que el principio de prevalencia no es una regla sobre distribución de competencias ${ }^{14}$ sino una regla para resolver conflictos entre normas ${ }^{15}$. No excluye ni reduce las competencias autonómicas ni aumenta de ninguna forma las estatales. Ni siquiera es una regla que sirva para delimitar competencias entre el Estado y las Comunidades Autónomas en casos dudosos o de superposición de títulos competenciales ni entraña una presunción provisional en favor de la estatal en tanto se dirima la competencia ${ }^{16}$. O sea, que cuando un mismo aspecto pueda estar comprendido en un ámbito de competencia estatal y en otro de competencia autonómica, la prevalencia no sirve para decantarse por aquélla ${ }^{17}$.

\footnotetext{
${ }^{14}$ No obstante, algunos autores sí le han dado ese significado. Vid. PAREJO ALFONSO, L., La prevalencia del Derecho estatal sobre el regional, CEC, Madrid, 1981, pp. 110 y 113, y BALAGUER CALLEJÓN, F., Fuentes del Derecho, Tecnos, Madrid, 1992, pp. 237 y ss.

${ }^{15}$ Vid. GARCÍA DE ENTERRÍA, E., y FERNÁNDEZ, T. R., Curso..., I, cit., p. 381; FERNÁNDEZ FARRERES, G., "Colisiones normativas y primacía del Derecho estatal" en Estudios sobre la Constitución Española. Homenaje al Profesor Eduardo García de Enterría, Civitas, Madrid, 1991, I, p. 541; TEJEDOR BIELSA, J. C., La garantía constitucional de la unidad del ordenamiento..., cit., pp. 90 y ss.; DE OTTO Y PARDO, I., "La prevalencia del Derecho estatal...", cit., pp. 68 a 70. La idea es certera, aunque incompleta porque la prevalencia no es sólo una regla de conflicto de normas, como se verá.

Por el contrario el principio de competencia no resuelve conflictos entre normas: no es ésa su función primigenia. Sirve para enjuiciar una sola norma, estatal o autonómica, en directa relación con la distribución de competencias. Así, aunque una norma estatal no entre en contradicción con ninguna norma autonómica, será inconstitucional y nula si no puede invocar una competencia del Estado. Y a la inversa: una norma autonómica será inconstitucional y nula aunque no contradiga ninguna norma estatal si, pese a ello, ha invadido las competencias del Estado. Así, una Ley autonómica de turismo no puede regular ningún contrato de servicios turísticos aunque cubra una laguna del Derecho estatal y, por tanto, no lo contradiga de ninguna forma, o aunque se limite a reproducir una norma estatal: incurrirá en incompetencia. Cosa distinta, es que existiendo ya dos normas, una estatal y otra autonómica, en contradicción resuelva el problema determinando que una de ellas está viciada de incompetencia y consecuentemente es nula. Pero, incluso así, lo que resuelve es el ajuste de cada una de esas normas con la distribución de competencias, no el ajuste de esas normas entre sí. Y si la contradicción entre dos normas se resuelve así, para nada hace falta acudir al principio de prevalencia.

${ }^{16}$ No creo que la prevalencia del Derecho estatal sirva para, entretanto se resuelve sobre dos normas en conflicto, aplicar la norma estatal de manera provisional, aunque esa opinión está extendida. Vid. MUÑOZ MACHADO, S., Derecho público de las Comunidades Autónomas, cit., I, p. 528. Si acaso es así cuando la norma estatal sea posterior. Pero en caso contrario, más bien creo que la presunción de constitucionalidad de la norma autonómica posterior debe llevar a entender que es compatible con el Derecho estatal anterior y, por ende, a su aplicación. Para que sea de otra forma habrá que suspender la norma autonómica y para ello tiene el Estado la vía privilegiada del art. 161.2 CE. En ese sentido, COSCULLUELA MONTANER, L., "El control...", cit., p. 1749.

${ }^{17}$ GARCÍA DE ENTERRÍA, E., y FERNÁNDEZ, T. R., Curso..., I, cit., p. 386, afirman expresamente que la prevalencia "tampoco (permite) sostener un principio interpretativo que postule una interpretación favorable en favor de la titularidad estatal (como... hizo... con torpeza el republicado Tribunal de Garantías)".
} 


\subsection{No hay prevalencia sin competencia}

La prevalencia del Derecho estatal sólo es de aplicación tras el principio de competencia, o sea, cuando éste no sea suficiente para resolver la situación. Dicho de otra forma, el principio de prevalencia sólo es de aplicación cuando el Estado y la Comunidad Autónoma permanezcan dentro del ámbito de sus respectivas competencias ${ }^{18}$. Por tanto, el principio de prevalencia no es de aplicación:

a) si la norma estatal de que se trate ha desbordado las competencias del Estado: en tal caso, no sólo no prevalecerá sobre el Derecho autonómico sino que será inconstitucional y nula (salvo en los casos, muy reducidos, en los que pueda subsistir con valor meramente supletorio; en cualquier caso, por tanto, sin prevalencia de ningún género). Como dice Muñoz Machado, "sin competencia, no hay prevalencia" 19 .

Puede que en algunos casos haya que decantarse por la competencia estatal, pero nunca en virtud del principio de prevalencia. Podrá basarse en el simple dato de que lo que puede corresponder a las Comunidades Autónomas es sólo lo no atribuido al Estado por la misma Constitución (según dice el primer inciso del art. 149.3 CE). Siendo así, lo que quede comprendido en alguno de los 32 apartados del art. 149.1 $\mathrm{CE}$ y aparentemente en alguna de las materias que un Estatuto atribuye a su respectiva Comunidad, es que realmente no está ni puede estar incluido en éstas. Por ejemplo, toda la legislación mercantil es del Estado (art. 149.1.6 $\mathrm{CE}$ ) y toda la defensa de los consumidores es exclusiva de las Comunidades Autónomas; ahora bien, si una posible regulación es al mismo tiempo de la materia "legislación mercantil" y de la materia "defensa de los consumidores", es obligado concluir que, a efectos de la delimitación de materias en que se basa la distribución de competencias, entra en aquélla materia y no en ésta de modo que, consiguientemente, será competencia del Estado y no de ninguna Comunidad. Y lo mismo si ese aspecto de la defensa de los consumidores entra en la materia "pesas y medidas" (art. 149.1.12a), "comercio de armas" (art. 149.1.26"), etc. O sea, que en las zonas de intersección de dos materias, hay que priorizar las enunciadas en el art. 149.1 CE frente a las inventadas por los Estatutos. Pero ello por una aplicación elemental de la primera afirmación del art. 149.3 CE que nada tiene que ver el principio o regla de prevalencia. Con todo, tal vez no sea ocioso aclarar que seguramente no quepa priorizar las competencias del Estado frente a las de las Comunidades Autónomas cuando aquéllas no deriven del art. 149.1 CE sino de su expreso reconocimiento estatutario o de la cláusula residual de segundo grado que también contiene el art. 149.3 CE o incluso cuando las competencias autonómicas tengan apoyo explícito en el art. 148.1 CE. Sea como fuere, todo eso es problema de distribución de competencias y nada dice a este respecto el principio de prevalencia.

${ }^{18}$ MUÑOZ MACHADO, S., Derecho público de las Comunidades Autónomas, cit., I, pp. 525-526. LEGUINA VILLA, J., "Notas sobre los principios de competencia y prevalencia en la legislación compartida", REA$L A, \mathrm{n}^{\circ} 258$ (1993), p. 233, lo expresaba así: “... la prevalencia del Derecho estatal no... juega en contra del principio de competencia sino sólo en su defecto”. Igualmente FERNÁNDEZ FARRERES, G., Sistema de Derecho Administrativo, Civitas, Madrid, 2a ed., 2014, I, p. 380; y en La contribución..., cit., p. 428, explica: "la prevalencia de la norma estatal sobre la autonómica presupone que ambas normas actúan en su propia esfera de competencia, de manera que si una de ellas es ineficaz e inválida -siempre por razón de la competencia asignada al ente de la que procede- no habrá colisión que deba ser resuelta dando un valor superior a la norma estatal. En tales casos, antes bien, la regla de la primacía del Derecho estatal ha de quedar marginada, debiéndose acudir al criterio de la competencia para encontrar la solución a la aparente colisión...".

${ }^{19}$ Asimismo, COSCULLUELA MONTANER, L., "El control...”, cit., p. 1755. Esto, por cierto, 
b) si la norma autonómica se ha dictado desbordando la competencia de la respectiva Comunidad Autónoma e invadiendo competencias estatales. En tal supuesto, no hará falta invocar el principio de prevalencia, lo que será por completo improcedente: será sólo el principio de competencia el que resolverá el problema y el que llevará a la nulidad de la norma autonómica. O sea, que también a este respecto puede decirse que sin competencia no hay prevalencia: sin competencia autonómica no hay prevalencia estatal sino nulidad de la norma autonómica por incompetencia.

Queda claro, por tanto, que el principio de prevalencia sólo despliega sus efectos tras aplicar y agotar todas las posibilidades del principio de competencia. En ese sentido, acierta el TC. Su error está, según creo, en haber llevado el principio de competencia más allá de su ámbito y no dejar función alguna al de prevalencia. Y queda claro, asimismo, que caen por tierra todas las objeciones alzadas contra el principio de prevalencia como devastador de la Constitución y de su delimitación de competencias. Nada de eso: es complementario del principio de competencia y sólo juega tras él allá donde éste no alcanza a resolver los problemas.

\subsection{Las normas estatales prevalentes no reducen las compe- tencias autonómicas y su vulneración no entraña vicio de incompetencia}

No sólo es que el principio de prevalencia no afecte de ninguna manera a las competencias autonómicas. Tampoco el hecho de que el Estado apruebe normas que, precisamente en virtud de este principio, se imponen a la legislación de las Comunidades Autónomas excluye ni reduce la competencia de éstas. Por ello, tampoco comporta nunca un vicio de incompetencia ${ }^{20}$; esto es, la norma autonómica que contradiga una norma estatal prevalente no incurre en incompetencia sino en otro vicio.

desbarata buena parte de las objeciones de DE OTTO y PARDO, I., "La prevalencia...", que en pp. 72 y ss. se basaba en la validez ilimitada del Derecho estatal gracias a su supletoriedad para poner de relieve una supuesta diferencia esencial entre nuestro Estado autonómico y los federales y la imposibilidad de acoger en aquél la prevalencia.

${ }^{20}$ Ello salvo que se quiera convertir cualquier ilicitud en vicio de competencia y hagamos de éste un concepto omnicomprensivo. Forzando las cosas, quien hace algo contrario a Derecho incurre en incompetencia porque, a fin de cuentas, si algo le está prohibido cabrá decir que no es competente para hacerlo. Por esa vía podría decirse que si el Consejo de Ministros viola un derecho fundamental incurre en incompetencia; incluso que no es competente para modificar las Constitución. A ello se ha tendido a veces. Lo apuntan certeramente GARCÍA DE ENTERRÍA, E., y FERNÁNDEZ, T. R., Curso..., I, p, 684: es "necesario acudir a él (al vicio de incompetencia) cuando la realidad ofrece irregularidades que el ordenamiento no ha llegado a aislar como vicios independientes". De hecho, la historia del contencioso-administrativo conoce epi- 
Nadie dice que las competencias autonómicas queden reducidas por el hecho de que deban respetar los preceptos materiales de la Constitución y que, en consecuencia, no puedan vulnerar los derechos fundamentales o establecer discriminaciones entre los españoles o alzar obstáculos a la libre circulación... Con razón, nadie ve en ello una reducción de las competencias autonómicas sino un límite material a su ejercicio: tiene competencias en materia de urbanismo o de comercio o lo que sea, pero no puede ejercerlas de cualquier forma, no puede dar a sus normas cualquier contenido. Y claro está que eso no supone reducción alguna de tales competencias.

Pues lo mismo sucede con las normas estatales que, precisamente por el principio de prevalencia (o de superioridad) del Derecho estatal se imponen a las Comunidades Autónomas: sólo entrañan límites materiales al ejercicio de las competencias autonómicas; no exclusión o reducción de tales competencias que permanecen incólumes. Son canon de constitucionalidad y por ello su vulneración determinará una inconstitucionalidad indirecta o mediata, pero no por incompetencia. Cada Comunidad Autónoma y sólo ella seguirá ostentando la competencia que tenga atribuida en virtud del bloque de la constitucionalidad; en su caso, ostentará y seguirá ostentando una competencia exclusiva. Lo que sucederá es que no podrá ejercerla en cualquier sentido ni dando a sus normas y actos cualquier contenido: tendrá un límite material. Si lo vulnera, no estará incurriendo en incompetencia, sino ejerciendo ilícitamente su competencia. El resultado (es decir, la norma o el acto que apruebe) estará viciado, será antijurídico, pero no por incompetencia sino por un vicio material, por ejercicio ilícito de su competencia. Habrá, según suele decirse, una inconstitucionalidad mediata o indirecta, pero no por incompetencia ${ }^{21}$. No diríamos, por ejemplo, que incurre en incompetencia el Ayuntamiento que aprobara una ordenanza sobre recogida de basura que contradijera una ley sobre residuos: el Ayuntamiento es y sigue siendo competente para regular ese servicio municipal; por tanto, la ordenanza no estaría viciada de incompetencia; el vicio estará en la vulneración de un límite material. Pues lo mismo hay que decir cuando se trata de normas autonómicas que simplemente contradigan normas estatales prevalentes.

sodios de este género cuando en determinados recursos no podían invocarse todos los vicios y sí los de incompetencia. Pero en general supone una forma burda de afrontar los problemas, un engorro, una distorsión y un ataque a la lógica. Y no está de ninguna forma justificado para el problema que nos ocupa porque sí hay medios de combatir esos otros vicios.

${ }^{21}$ Precisamente porque se trata de un vicio material, de una inconstitucionalidad material, aunque indirecta o mediata, está también justificado afirmar que las normas autonómicas deben ser objeto de una interpretación conforme a la legislación estatal prevalente, al modo en que se impone una interpretación conforme a la Constitución. Cuando sea posible una interpretación de la norma autonómica que la compatibilice con la norma estatal, a ella debe estarse. El principio de prevalencia incluye también un principio de "interpretación conforme", esto es, un mandato de interpretar el Derecho autonómico para, en lo posible, hacerlo conforme al estatal y evitar su invalidez o su pura inaplicación. 
Todo esto parece obvio en los casos de materias de la competencia exclusiva de una Comunidad Autónoma pero afectadas tangencialmente por las normas dictadas por el Estado en virtud de sus competencias sobre otras materias: así, el hecho de que una Comunidad no pueda aprobar normas sobre turismo que vulneren lo establecido por el Estado sobre procedimiento administrativo común no significa que se reduzca la competencia autonómica sobre turismo; y si en efecto dicta una norma sobre turismo que vulnere una norma estatal sobre procedimiento administrartivo común es absurdo decir que esté invadiendo las competencias estatales sobre procedimiento administrativo común: estará ejerciendo sus competencias pero con contenido ilícito. Pero es también cierto en cualquier supuesto de compartición de materias. En especial, es cierto en el caso en que al Estado correspondan las bases y a la Comunidad Autónoma el resto: si ésta aprueba una norma en esa materia (v. gr. medio ambiente) que contradice las bases estatales sobre esa misma materia es contra toda razón decir que está invadiendo la competencia estatal sobre las bases: con toda evidencia estará actuando contra las bases, no ejerciendo la competencia para establecer las bases ${ }^{22}$. Y lo mismo hay que decir si vulnera una norma del Estado dictada en virtud de las competencias de éste sobre coordinación: decir ante tal vulneración que la Comunidad está asumiendo las competencias estatales de coordinación será una sandez. Y si el Estado aprobara una ley de armonización, afirmar que la norma autonómica que no la respetase está invadiendo las competencias estatales de armonización sería un despropósito que no resiste un análisis serio. Cierto es que el TC afirma lo contrario ${ }^{23}$ y que lo mismo se desliza incluso entre la doctrina más riguros ${ }^{24}$. Pero hay que erradicar esa idea errónea que es el germen de otros muchos errores, que hipertrofia el principìo de competencia, genera confusión y, a la postre, consecuencias funestas. En todos estos casos la relación entre las normas estatales (sean básicas o de coordinación o de cualquiera de las modalidades del art. $150 \mathrm{CE}$, o incluso leyes orgánicas o hasta tratados interna-

\footnotetext{
22 Parece una perogrullada o alternativamente un sofisma, pero no lo es: por la naturaleza de las cosas, ninguna Comunidad Autónoma invade las competencias estatales sobre las bases porque no aprueba ninguna norma que presente como bases ni que pretenda ser de aplicación en toda España ni fijar el mínimo común uniforme o algo por el estilo. Por tanto, obviamente, no invade la competencia estatal sobre bases ni incurre en incompetencia. Lo que las Comunidades Autónomas pueden hacer es contradecir las bases en cuyo caso su norma estará viciada por esa contradicción material, no por incompetencia, y será el principio de prevalencia el que determinará su inconstitucionalidad.

${ }^{23} \mathrm{El} \mathrm{TC}$ ha tendido a ver en estos casos de contradicción de norma autonómica con las bases un supuesto de incompetencia (así, ya con claridad al menos en SSTC 60, 61 y 62/1993, de 18 de febrero).

${ }^{24}$ Ejemplo, entre otros, ofrece GARCÍA LUENGO, J., "El desplazamiento...", que afirma en p. 199 que "la normativa autonómica debe respetar el contenido de la normativa básica porque alterarlo sería tanto como invadir el campo de lo básico y quebrar la distribución competencial...". Cierto lo primero, pero no lo segundo, aunque lo expresa en términos ("sería tanto como...") que demuestran que realmente no es así, que se trata de una asimilación. Pero no procede esa asimilación.
} 
cionales suscritos por el Estado) y las normas autonómicas no se pueden explicar en virtud del principio de competencia ni dan lugar a vicio de incompetencia; no es que la Comunidad ejerza una competencia que no es suya, que invada las competencias del Estado, sino que ejerce ilícitamente su competencia sin salirse de ella.

Por lo mismo, hay que desterrar la idea de que las normas estatales contribuyen de alguna forma a delimitarlas competencias, lo que sobre todo se ha afirmado -y lo que sobre todo importa negar- de las leyes básicas ${ }^{25}$. Paralelamente se puede y debe depurar y reducir el concepto de bloque de la constitucionalidad ${ }^{26}$. Asimismo se debe negar que la aprobación de una norma estatal prevalente produzca la preclusión o cierre de un espacio antes abierto a la competencia autonómica ${ }^{27}$. Prueba irrefutable de

\footnotetext{
${ }^{25}$ Importa aclarar que las normas básicas ni delimitan las competencias ni contribuyen a delimitarlas más concretamente. El TG entiende lo contrario. Sobre esta jurisprudencia vid. FERNÁNDEZ FARRERES, G., La contribución..., pp. 48 y ss. Pero es una idea equivocada. Las normas básicas -como tampoco las normas estatales "plenas" ni las de armonización- no alteran un ápice la competencia estatal ni las autonómicas ni las deslindan. Cierto que son canon de constitucionalidad de las normas autonómicas, pero no porque fijen el contorno exacto del ámbito material de las competencias autonómicas sino porque, dejando éste intacto, condicionan el posible sentido de las competencias autonómicas; o sea, no afectan a la posibilidad autonómica de dictar normas sino a la libertad para dar contenido a esas normas. Y, por supuesto, las leyes básicas no establecen límites sólo para la correspondiente legislación de desarrollo sino para toda la legislación autonómica en cualquier materia; por ejemplo, la LRBRL impone límites a la legislación urbanística, ambiental o cualquier otra autonómica. Pero, insistamos, no porque delimite competencias sino porque enmarca el posible contenido de las normas que aprueben las Comunidades en el ejercicio de sus competencias. No es cuestión del principio de competencia sino de la prevalencia del Derecho estatal, de todo el Derecho estatal (salvo el supletorio). El TC coloca equivocadamente todos estos problemas en el terreno de la competencia, y así ha podido ir tirando sin invocar el principio de prevalencia, como explica el mismo FERNÁNDEZ FARRERES, G., La contribución..., p. 433. Forzoso es reconocer que el error del TC ha inducido a otros y que ya no es extraño en la doctrina afirmar que las bases delimitan o, al menos, concretan la delimitación de competencias.

${ }^{26}$ En realidad, afirmar si las leyes básicas u otras forman parte del bloque de la constitucionalidad es un problema terminológico y menor. Depende del concepto que se acoja de bloque de la constitucionalidad. Si éste se identifica, como de ordinario se hace, sólo con las normas que atribuyen y delimitan las competencias, entonces las leyes básicas no deben incluirse en el bloque de la constitucionalidad. Si se identifica con todas las normas que el art. 28.1 LOTC permite considerar canon de constitucionalidad, entonces sí entran en ese concepto. Y es que acertadamente el art. 28.1 LOTC se refiere a dos tipos de normas que, además de la Constitución, son canon de constitucionalidad: las dictadas "para delimitar las competencias del Estado y de las diferentes Comunidades Autónomas" y aquellas otras dictadas "para regular o armonizar el ejercicio de las competencias de éstas". Sólo en este segundo grupo pueden entrar las leyes básicas, las leyes de armonización y otras muchas normas estatales. Las del primer grupo son necesarias para aplicar el principio de competencia; las del segundo para aplicar el de prevalencia.

${ }^{27}$ Vid. MUÑOZ MACHADO, S., Tratado de Derecho Administrativo y Derecho público general, Iustel, Madrid, II, 2006, p. 271; y en p. 273 añade: "aunque norma de conflicto (y no de competencia) tiene un efecto final propio de las reglas de competencia, ya que permite a un legislador (el estatal) ocupar un espacio normativo determinado, impidiendo en lo sucesivo a otro (el autonómico) la aprobación válida de normas,
} 
que no se produce tal preclusión es que, tras la nueva norma estatal prevalente, la Comunidad podrá ahora (o incluso deberá) dictar nuevas normas compatibles con la es$\operatorname{tatal}^{28}$. Así que la prevalencia, ni siquiera indirectamente, produce efectos sobre el sistema de distribución de competencias.

En suma, por todas las vías queda claro que ni el principio de prevalencia, en sí mismo, ni el hecho de que el Estado apruebe concretas normas prevalentes, afecta ni reduce un ápice a las competencias autonómicas, quod erat demonstrandum.

Pero queda también demostrado, y es tan o más importante que lo anterior, que la contradicción entre norma estatal y autonómica puede producirse con frecuencia permaneciendo ambas dentro de sus respectivas competencias y que, entonces, lo que debe aplicarse es el principio de prevalencia, no forzar y deformar todo para, contra viento y marea, aplicar también entonces un principio de competencia deforme.

lo que es equivalente exactamente a una redistribución parcial de las competencias que privara a este último legislador de las que antes tenía". Sobre esta preclusión, en abstracto, COSCULLUELA MONTANER, L., Manual..., p. 53, explica que "determina que una materia puede ser regulada por más de un ordenamiento, pero la regulación por uno de ellos excluye la posibilidad de que se regule por el otro que por lo general sólo podía hacerlo en tanto que el primer ordenamiento no lo hiciera". Esa preclusión está prevista en el art. 72 de la Ley Fundamental de Bonn: "En el ámbito de la legislación concurrente, los Länder tienen la facultad de legislar mientras y en la medida que la Federación no haya hecho uso medainte ley de su competencia legislativa". Pero, además de que eso sólo está establecido para los casos de legislación concurrente que tienen en Alemania un régimen distinto y que no es extensible a los demás en los que también prevalece el Derecho federal, no es normalmente lo que sucede en España ni en los supuestos de leyes básicas ni de coordinación ni de armonización... Mucho menos en otros en los que la norma dictada por el Estado en una materia prevalezca sobre la de una Comunidad Autónoma en otra materia, incluso de la exclusiva competencia de ésta. Ese cierre o preclusión sólo se producirá excepcionalmente en el caso en el que la norma estatal, por su contenido concreto, impida toda norma autonómica. Así, cuando el Estado, de conformidad con el art. 149.1.13 ${ }^{\mathrm{a}} \mathrm{CE}$, proclamó la más absoluta libertad de horarios comerciales, produjo esa preclusión pese a que tal aspecto estaba en principio comprendido en las competencias autonómicas sobre comercio interior. Pero este efecto sólo será ocasional y admisible muy excepcionalmente.

${ }^{28}$ Precisamente sobre estas ideas debe construirse el tratamiento a las normas autonómicas que repiten normas estatales, cuestión sobre la que sigue siendo capital LÓPEZ BENÍTEZ, M., “¿Interdicción de las leges repetitae? (Comentarios a la Sentencia del Tribunal Constitucional 62/1991, de 22 de marzo)", RAAP, $n^{\circ} 6$ (1991), pp. 131 y ss. En virtud del principio de competencia, debe entenderse prohibida esta posibilidad: por ir al caso más extremo, se comprende que la Comunidad Autónoma no puede incluir en sus normas un precepto penal ni siquiera aunque sea la fidedigna reproducción de algún artículo del Código Penal porque, con independencia de ello, estaría invadiendo competencias estatales. Pero el principio de prevalencia no prohíbe esta reproducción; así, por ejemplo, siendo el comercio competencia exclusiva de una Comunidad Autónoma, nada impide que reproduzca una norma estatal sobre horarios comerciales dictada de conformidad con el art. 149.1.13 $\mathrm{CE}$. 


\section{LA PREVALENGIA COMO REGLA DE RESOLUGIÓN DE CONFLICTOS NORMATIVOS Y GOMO LÍMITE MATE- RIAL AL EJERGICIO DE LAS COMPETENGIAS AUTONÓ- MICAS}

Ya se ha dicho que es común afirmar que la prevalencia es una regla de resolución de conflictos entre normas. Es cierto y nos ha servido para descartar que afecte a la distribución de competencias. Pero con eso no se agota la virtualidad del principio ni se capta su esencia ni toda su potencia. Si eso fuese todo, la prevalencia sólo decidiría sobre la aplicabilidad de las normas ya producidas válidamente y que seguirían siendo válidas. Pero no es así o, por lo menos, no es así siempre y sólo así. La verdad, por el contrario, es que la prevalencia es esencialmente otra cosa y, por derivación, sirve en ocasiones para resolver conflictos entre normas. De hecho, la prevalencia ha de ser ya tenida en cuenta y despliega sus efectos antes de que existan dos normas en conflicto.

La prevalencia supone, ante todo, que si una Comunidad Autónoma pretende aprobar una norma sobre régimen local o urbanismo o universidades o cualquier otra materia en que tenga competencias debe hacerlo respetando el Derecho estatal previo y prevalente que exista en ese momento. Si no lo hace así, o sea, si aprueba una norma que no respeta el Derecho estatal preexistente y prevalente, la norma autonómica será ilícita, antijurídica, tendrá un vicio; no un vicio de incompetencia, como ya hemos explicado, pero sí un vicio material por su contenido, por haber ejercido su competencia sin respetar las normas a las que estaba sometida, por vulnerar aquéllas que limitan o disciplinan -las que "regulan o armonizan el ejercicio", por decirlo en los términos del art. 28.1 LOTG- el ejercicio de su competencia. Háblese de inconstitucionalidad indirecta o mediata o no; de nulidad o no. Esto último lo abordaremos luego. Lo que en este momento hay que subrayar es que la prevalencia juega también aquí, y juega decisivamente, incluso antes de que existan dos normas en conflicto; y cuando ya existan, si la autonómica vulnera la estatal previa, no juega para resolver cuál es de aplicación preferente sino para determinar que una de ellas es ilícita e inválida. Claro está que nada de esto se da cuando estamos realmente ante puras reglas de resolución de conflictos normativos ${ }^{29}$.

${ }^{29}$ Por ejemplo, son impensables estos efectos para las reglas de resolución de concursos opositivos de normas que contiene el art. 8 CPen o para las muchas de Derecho Internacional privado o para las del Derecho interregional civil... Igualmente la regla de resolución de conflicto establecida por el TC según la cual, cuando dos normas prevean para el mismo supuesto pena y sanción administrativa y no puedan acumularse, se ha de aplicar siempre aquélla: esta regla no produce nunca la invalidez de la norma administrativa sancionadora, aunque esté condenada a su inaplicabilidad perpetua. Y, desde luego, nadie comete una ilicitud por aprobar una de esas normas sancionadoras administrativas en las que todo lo subsumible 
¿Qué es, pues, en esencia, la prevalencia del Derecho estatal? Es, antes que nada, un límite material al ejercicio de las competencias autonómicas: impone un límite al ejercicio de todas las potestades y competencias autonómicas, límite en cuya virtud en la misma elaboración de sus normas y decisiones la Comunidad debe tener en cuenta el Derecho estatal prevalente; un límite de acuerdo con el cual ni siquiera debe aprobarse la norma autonómica contraria a la estatal. Después, porque es un límite y como consecuencia de ello, juega alternativamente, según los casos, como causa de invalidez o de mera inaplicación -general o singular- de las normas autonómicas incompatibles con el Derecho estatal prevalente. Sólo en este último caso funciona como norma de resolución de conflictos entre normas, función que, como ya se ve meridianamente, no es la suya primigenia ni expresa o capta su sustancia.

Igual que no decimos que la jerarquía normativa sea una regla de resolución de conflictos entre Leyes y Decretos o entre éstos y las Órdenes Ministeriales -aunque a la postre eventualmente pueda coadyuvar a resolver las oposiciones entre esas normas de distinto rango- tampoco la prevalencia del Derecho estatal debe ser vista exclusiva ni aun prioritariamente como regla de resolución de conflictos internormativos. Más que ello es un límite sustantivo o material al ejercicio de las competencias que opera antes de que se ejerzan.

Lo que aquí en el fondo luce es la prevalencia como superioridad del Derecho estatal sobre los autonómicos, conforme a lo que antes explicamos. La prevalencia como mera regla de resolución de conflictos normativos es más bien una concreción de la prevalencia como superioridad.

En cualquier caso, se explique de un modo u otro, la prevalencia del Derecho estatal comporta primordialmente un límite material al ejercicio de las competencias autonómicas. Es también, pero secundariamente, criterio de resolución de conflictos de normas.

\footnotetext{
en ellas ya lo es en alguna norma penal. Lo mismo puede decirse de las demás reglas que sean sólo resolutorias de conflictos de normas. Pero la prevalencia del Derecho estatal sí es capaz de determinar la nulidad de la norma autonómica que se oponga a una estatal previa y prevalente. Y la autoridad autonómica que aprueba normas contrarias a las estatales prevalente previas sí que comete una indudable ilicitud. Es más, si se dieran los demás requisitos para ello, podría incluso incurrir en delito; así, la autoridad administrativa autonómica que con plena conciencia de ello dicte una resolución (apruebe una norma) manifiestamente contraria al Derecho estatal prevalente podría estar cometiendo un delito de prevaricación.
} 


\section{VI. ¿QUÉ NORMAS ESTATALES PREVALEGEN SOBRE QUÉ NORMAS AUTONÓMICAS?}

Toda norma del Estado aprobada en el ejercicio de sus competencias prevalece sobre cualquier norma de las Comunidades Autónomas que éstas pretendan aprobar o que ya hayan aprobado en el ejercicio de las suyas. Con frecuencia se ha negado, cada cual a su manera, esta afirmación ${ }^{30}$ que, por ello, conviene explicar.

La prevalencia del Derecho estatal lo es de todo el Derecho estatal, de todas sus normas. No importa su rango ${ }^{31}$ ni qué organo estatal la haya aprobado (las Cortes, el Gobierno, cualquier órgano de la Administración del Estado y de sus entes institucionales como puedan ser sus autoridades independientes, Banco de España, Comisión Nacional de los Mercados y la Competencia, Comisión del Mercado de Valores...). Tampoco importa que se haya aprobado en virtud de una competencia estatal sobre toda una materia o de una competencia en una materia compartida de cualquier forma: es irrelevante que se haya aprobado en virtud del art. 149.1 CE o tenga otro apoyo en el bloque de la constitucionalidad ${ }^{32}$. También las aprobadas en virtud del art. $150 \mathrm{CE}$ son prevalentes ${ }^{33}$. Asímismo las que haya podido dictar por estar resevadas a las leyes orgánicas y los tratados internacionales, aunque en esto influyan también otros factores. En cualquier caso, la norma estatal aprobada por el Estado dentro de sus competencias se impondrá a las nomas autonómicas en virtud de la prevalencia. Así que go-

\footnotetext{
${ }^{30}$ Una síntesis de las distintas posturas doctrinales a este respecto en RUÍZ LÓPEZ, M. A., "La cláusula de prevalencia del Derecho estatal...", pp. 146 a 148.

${ }^{31}$ MUÑOZ MACHADO, S., Derecho público de las Comunidades Autónomas, cit., I, p. 528; y el mismo autor en Tratado..., II, cit., p. 271. También PAREJO ALFONSO, L., La prevalencia..., cit., p. 112.

${ }^{32} \mathrm{El}$ "Informe de la Comisión de Expertos sobre Autonomías" dirigido por García de Enterría en 1981 se centró en destacar la prevalencia de las normas estatales dictadas ex art. 149.1 CE. Y eso fue lo que se plasmó en el art. 4 de la Ley Orgánica de Armonización del Proceso Autonómico: "Las normas que el Estado dicte en el ejercicio de las competencias que le reconoce el art. 149.1 de la Constitución prevalecerán sobre las normas de las Comunidades Autónomas". Desde luego, es cierto lo que decía (la STC que lo anuló no lo negó) y se dirigía a combatir que la prevalencia quedara obstaculizada por la proclamación estatutaria de numerosas competencias autonómicas exclusivas. Pero no hay que circunscribir la prevalencia a las normas dictadas en virtud del art. 149.1 CE.

${ }^{33}$ Es especialmente acertada a este respecto la exposición de GARCÍA DE ENTERRÍA, E., y FERNÁNDEZ, T. R., Curso..., I, cit., pp. 382 a 387. Se refieren expresamente como beneficiarias de la prevalencia a las bases, a la legislación estatal en materias en que toda la ejecución corresponde a las Comunidades Autónomas, a las tres modalidades de leyes estatales previstas en el art. $150 \mathrm{CE}$, a las que dicten en virtud de la coerción estatal (art. $155 \mathrm{CE})$... Pero después se refieren también a los demás supuestos de "superposición de títulos competenciales" producidos porque "los criterios de distribución competencial son necesariamente heterogéneos, de modo que se entrecruzan...". Vid. también GARCÍA LUENGO, J., "El desplazamiento...", pp. 200-201.
} 
zan de esta prevalencia las normas estatales sobre nacionalidad, legislación penal, mercantil, laboral, civil, seguridad pública, medio ambiente, metrología, etc.

De otro lado, esa prevalencia afecta a cualquier norma autonómica con independencia de su rango y del tipo de competencia que ejerza la Comunidad Autónoma ${ }^{34}$. La prevalencia se proyecta sobre la totalidad del ordenamiento autonómico. En particular, rige también, pese a la literalidad del art. 149.3 CE, en aquellas materias que son por completo de la exclusiva competencia autonómica. Si una materia es de la exclusiva competencia autonómica, el Estado no podrá aprobar normas sobre esa materia y, si lo hace, incurrirá en incompetencia, de modo que no será prevalente (recuérdese: sin competencia no hay prevalencia). Parece que simplonamente es en lo que pensó el art. 149.3 CE. Pero el Estado puede, invocando su competencia en otras materias, dictar normas que de alguna forma interfieran o se superpongan sobre la materia de competencia autonómica exclusiva ${ }^{35}$. Cuando así suceda, la norma estatal prevalecerá sobre las autonómicas dictadas en el ejercicio de una competencia exclusiva sobre una materia ${ }^{36}$. Hay ya notables ejemplos de ello ${ }^{37}$.

Así que, en suma, siempre que el Estado permanezca dentro de sus competencias, la prevalencia es de todo el Derecho estatal sobre todo el Derecho autonómico. Lo que, por cierto, es lo mismo que consagran tanto el art. VI.2 de la Constitución de los Estados Unidos de América como el art. 31 de la Ley Fundamental de Bonn, preceptos en los que no se establece a este respecto ninguna distinción.

${ }^{34}$ Sólo quedan al margen los Estatutos de Autonomía porque no son sólo parte del ordenamiento autonómico sino también del estatal y sólo están subordinados a la Constitución (al menos, en tanto permanezcan dentro del contenido que les es propio). En esto nuestra prevalencia se diferencia de la primacía del Derecho de la Unión Europea que afecta a las Constituciones de los Estados miembros como demuestra paladinamente la STJUE de 26 de febrero de 2013, as. C-399/11, Melloni, ap. 59.

${ }^{35}$ Lo apunta con acierto RUÍZ LÓPEZ, M. A., "La cláusula de prevalencia del Derecho estatal...", p. 157.

${ }^{36}$ Es lo que acaso pretendió excluir el art. 110 EAC de 2006: "El derecho catalán, en materia de las competencias exclusivas de la Generalitat, es el derecho aplicable en su territorio con preferencia sobre cualquier otro". Pero, aun sin anularlo, la STG 31/2010, de 28 de junio, abortó el intento al afirmar en su f. j. 59 que ese precepto "no impide la aplicación del Derecho del Estado emanado en virtud de sus competencias concurrentes" de modo que "el sentido del precepto se compadece sin dificultad con el art. 149.3 CE, cuyas cláusulas de prevalencia y supletoriedad no se ven menoscabadas" y sin que impida "el ejercicio de las competencias exclusivas del Estado ex art. 149.1 GE, sea cuando éstas concurren con las autonómicas sobre el mismo espacio físico u objeto jurídico, sea cuando se trate de materias de competencia compartida...".

${ }^{37}$ Basta citar los ejemplos de las Leyes estatales del Comercio Minorista y de Suelo: siendo el comercio interior y el urbanismo materias de la exclusiva competencia autonómica, el Estado, en el ejercicio de sus competencias sobre otras materias, ha aprobado esas leyes que sin ninguna duda prevalecen sobre todas las de las Comunidades Autónomas, incluidas las que hayan aprobado o pretendan aprobar en ejercicio de su competencia exclusiva sobre comercio y urbanismo. 
Dicho lo cual se comprende que no cabe constreñir la prevalencia del Derecho estatal a las materias compartidas ni enzarzarse en los interminables -y estériles- debates sobre el concepto de competencias autonómicas exclusivas ni polemizar sobre el uso correcto o abusivo que de él hacen los Estatutos: sean de verdad exclusivas o no, tienen el límite de respetar el Derecho estatal, sea el dictado en esas mismas materias sea en otras distintas. Lo importante para aplicar la prevalencia, en suma, no es si una materia es o no de la exclusiva competencia autonómica sino si el Estado ha aprobado su norma dentro de las suyas, lo que es muy diferente.

Tampoco cabe, en sentido contrario, negar la prevalencia justamente en los casos de materias compartidas ni, más concretamente, en el de bases y desarrollo, como también se ha hecho, para circunscribir la prevalencia a los supuestos, casi marginales en nuestro sistema, de competencias en puro régimen de concurrencia sobre una misma materia ${ }^{38}$. Todo eso sobra ${ }^{39}$.

En suma, el principio de prevalencia beneficia a toda norma estatal dictada sobre cualquier materia, en ejercicio de cualquier género de competencia (plena, básica, de coordinación, de armonización... y tenga su fundamento en el art. 149.1 CE o en cualquier otro precepto del bloque de la constitucionalidad) y se proyecta sobre cualquier norma de las Comunidades Autónomas correspondiente a la misma o a otra materia, incluidas las aprobadas o que se pretendan aprobar en el ejercicio de sus competencias exclusivas.

${ }^{38}$ Así, FERNÁNDEZ FARRERES, G., La contribución..., cit., pp. 428-429; y el mismo autor en Sistema..., I, p. 380; LEGUINA VILLA, J., "Notas sobre los principios...”, cit., p. 233; DE OTTO y PARDO, "La prevalencia...", cit., p. 68; y RODRÍGUEZ PORTUGUÉS, M., "Sobre los efectos de la legislación básica sobrevenida en la normativa autonómica", en Régimen jurídico básico de las Administraciones públicas. Libro homenje al Profesor Luis Cosculluela, Iustel, Madrid, 2015, p. 206. Pero sí aceptan la prevalencia entre bases y desarrollo, entre otros, PAREJO ALFONSO, L., La prevalencia del Derecho estatal sobre el regional, Centro de Estudios Constitucionales, Madrid, 1981, pp. 114-115; TORNOS MÁS, J., "El principio de prevalencia del Derecho estatal", Autonomía. pluralidad de ordenamientos y principios de relación, Generalitat de Catalunya/Instituts d'Estudis Autonòmics, Barcelona, 2000, pp. 92 a 94; y SANTAMARÍA PASTOR, J. A., Principios de Derecho Administrativo, Iustel, Madrid, $3^{\mathrm{a}}$ ed., 2015, I, p. 153.

39 Cabría objetar que hay otras explicaciones distintas de la prevalencia para justificar que las normas básicas, las dictadas por el Estado en virtud de sus competencias de coordinación (art. 149.1.13 ${ }^{\mathrm{a}}, 15^{\mathrm{a}}$ y $16^{\mathrm{a}} \mathrm{CE}$ ) o de acuerdo con cualquiera de los apartados del art. $150 \mathrm{CE}$ imponen un límite a las Comunidades Autónomas: los mismos conceptos de bases o de coordinación o de ley marco o de ley de transferencias o, sobre todo, de ley de armonización podrían justificar la vinculación a su contenido por la legislación autonómica y los límites que entrañan. Así lo apuntó DE OTTO, I., "La prevalencia...”, cit., p. 90. Pero no hay ningún inconveniente, sino todo lo contrario, en explicar esa superioridad y esos límites conforme al mismo principio de prevalencia del que todos estos supuestos no son nada más que una concreción. Máxime si se tiene en cuenta que los conflictos se pueden producir, no sólo entre leyes básicas y su legislación de desarrollo sobre una misma materia, sino también entre leyes básicas sobre una materia y leyes autonó- 
Problema específico es si también el Derecho estatal prevalece sobre lo establecido en los Estatutos de Autonomía. La primacía del Derecho de la Unión Europea, como es sabido, no se frena antes las Constituciones nacionales (STJUE de 26 de febrero de 2013, as. C-399/11, Melloni, apdo. 59). Igualmente en los sistemas federales el Derecho de la federación prevalece sobre las Constituciones de los Estado federados ${ }^{40}$. La situación en España es peculiar porque los Estatutos de Autonomía son también aprobados por ley estatal. Aun así, la solución debe estar en la misma dirección, al menos en tanto que los Estatutos desborden las materias que tienen reservadas.

\section{CONSEGUENGIAS DE LA PREVALENGIA EN CASOS DE CONFLICTO ¿DESPLAZAMIENTO O NULIDAD DE LA NORMA AUTONÓMICA?}

\subsection{Necesidad de distinguir tres supuestos}

La cuestión de las consecuencias de la prevalencia está íntimamente relacionada con la de quién puede aplicar este principio y esas consecuencias. Pero para proceder con la máxima meticulosidad en asunto que está resultando tan espinoso, vamos a abordar sucesivamente los dos planos.

Para analizar las consecuencias de la prevalencia, la doctrina ha considerado necesario distinguir diversos supuestos. Así debe hacerse. Ante todo hay que diferenciar dos situaciones: aquéllas en que la norma estatal y la autonómica sólo presentan una oposición ocasional, para determinado supuesto o grupo de supuestos; y aquéllas otras en que su contradicción es completa, abstracta y general ${ }^{41}$. O sea, entre el mero "concurso de normas" (aunque concurso conflictivo) y la "colisión opositiva de normas" $" 42$. En este segundo supuesto hay que distinguir, a su vez, según, la norma auto-

micas sobre cualquier otra: explicar esos dos fenómenos, sustancialmente iguales, conforme a principios diferentes es una complicación innecesaria.

${ }^{40}$ Explica SOSA WAGNER, F., "Para el debate...", cit., p. 37, que la sentencia del Tribunal Constitucional alemán de 10 de junio de 2009 "recuerda algo que por lo demás es pacífico y es que $<<$ el derecho de la Federación prevalece sobre el derecho constitucional de los Länder”. Por lo demás, en Estados Unidos el art. VI de su Constitución aclara expresamente que los jueces están vinculados a las normas federales "no obstante lo que en contrario disponga la Constitución o las leyes de cada Estado".

${ }^{41}$ Por todos, con especial claridad, vid. SANTAMARÍA PASTOR, J. A. Fundamentos..., cit., p. 330, que distingue entre, de un lado, "confluencia de facto sobre un supuesto concreto de normas dictadas desde perspectivas competenciales distintas y que, por lo tanto, no se oponen abstractamente entre sí" y de otro, "cuando el conflicto entre las dos normas es frontal y abstracto".

${ }^{42}$ Sobre esos conceptos y sus diferencias, vid. VILLAR PALASÍ, J. L., Derecho Administrativo. Introducción y teoría de las normas, Universidad de Madrid, 1968, pp. 414 y ss. 
nómica contraria a la estatal prevalente sea anterior o posterior a ella ${ }^{43}$. Analicemos estas distintas situaciones.

\subsection{Norma autonómica en concurso conflictivo con norma estatal: desplazamiento de la autonómica en un caso con- creto}

Hay concursos conflictivos entre normas de un mismo ordenamiento cuando dos o más de ellas resultan aplicables a ciertos supuestos y establecen un tratamiento jurídico incompatible entre sí (si no hay esa incompatibilidad habrá concurso de normas, pero no conflictivo, y se acumularán las consecuencias jurídicas previstas en cada una de ellas). Para su resolución se establecen distintos criterios (especialidad, consunción, subsidiariedad, etc.). También se producen concursos de normas de distintos ordenamientos que ocasionalmente pueden ser conflictivos, esto es, con soluciones no acumulativas sino excluyentes entre sí. En sus respectivos campos de aplicación sólo hay una zona de intersección y en ella no son acumulables los tratamientos jurídicos previstos por ambas. Pues bien, para el caso en que el concurso conflictivo se produzca entre una norma estatal y otra autonómica (ambas, desde luego, aprobadas dentro de sus respectivas competencias), el principio de nuestros desvelos lo resuelve en favor de la estatal. Simplemente en favor de la estatal sin atender al contenido o finalidad de cada norma; y sin que importe lo más mínimo cuál se aprobó antes y cuál después.

En todos estos concursos (sean intraordinamentales o interordinamentales) se produce simplemente el desplazamiento de una norma por la otra: en ese caso concreto, una norma se aplicará y la otra norma no. Nada más: la norma desplazada no tiene ni se le achaca ningún vicio (no vulnera a la otra ni vulnera de ninguna forma el ordenamiento). Por tanto, tampoco se la puede considerar inválida. Además, ni aun en el caso de que la prevalente sea posterior a la relegada, ésta queda derogada sino vigente para ser aplicada en otros muchos casos en que no se produzca la concurrencia. Llevado esto al caso de concurso entre norma estatal y autonómica, diremos entonces que ésta no vulnera a aquélla; que la norma autonómica no tiene ni se le imputa ningún vicio; que, desde luego, no es inconstitucional (ni siquiera con inconstitucionalidad mediata o indirecta); que, aunque la estatal sea posterior, no queda derogada. Sólo queda desplazada o relegada en ese caso pero permanecerá válida y vigente, dispuesta

${ }^{43}$ Así lo observó y lo desarrolló ya LASAGABASTER HERRARTE, I., Los principios de supletoriedad y prevalencia del Derecho estatal respecto al Derecho autonómico, Civitas, Madrid, 1991, pp. 147 y ss. Y COSCULLUELA MONTANER, L., "El control...", cit., p. 1755, distingue finalmente según la norma autonómica sea anterior a la estatal que contradice (en cuyo caso la deberá inaplicar cualquier tribunal) o posterior (en cuyo caso habrá nulidad que sólo podrá declarar el TC). 
a ser aplicada en cualquier otro caso en que no concurra con la estatal. Y, desde luego, si se planteara cualquier recurso o cuestión contra esa norma autonómica, tendría que ser desestimado.

Se trata del supuesto menos problemático de aplicación del principio de prevalencia y hasta da la impresión de que es el único en el que el TC le reconoce su papel sin suplantarlo por el de competencia.

Sólo cabe añadir que, en lo posible, debe tenderse a ver concurso de normas y no colisión opositiva cuando concurran estatales y autonómicas; o, incluso, que deben hacerse esfuerzos por considerar que no se trata de concursos opositivos y, por tanto, apurar las posibilidades interpretativas para aplicar las dos normas.

\subsection{Golisión de norma autonómica con norma estatal ante- rior: nulidad de aquélla}

Ya se dijo que toda norma autonómica debe respetar lo dispuesto en toda norma anterior del Estado dictada dentro de las competencias de éste; y se explicó asimismo que si no lo hace es ilícita, antijurídica; en concreto, inconstitucional, con inconstitucionalidad indirecta o mediata. No por vicio de incompetencia sino por un vicio material que afecta a su contenido. Inconstitucional desde su origen, pues cuando se aprobó ya existía una norma estatal a la que vulnera. Y, siendo todo ello así, la consecuencia ineluctable es la invalidez originaria de tal norma, más en concreto, la nulidad pues tal es el grado de invalidez que atribuye nuestro Derecho a las normas con vicios materiales ${ }^{44}$. Nulidad de la ley o del reglamento o, en su caso, de los actos. Si se plantea recurso o cuestión contra esa ley, reglamento o acto debe ser estimado y declararse su nulidad.

Ahora bien, nulidad y, además, eventualmente, otros efectos en distinto plano. Por ejemplo no cabe descartar la responsabilidad patrimonial de la Comunidad Autónoma por los daños que cause a terceros al incumplir el Derecho estatal o, incluso, la responsabilidad penal de las autoridades administrativas que aprueben esa norma o decisión claramente contraria a las normas estatales prevalentes. No es ocioso aclararlo porque también son efectos de la prevalencia del Derecho estatal y porque, dado que nuestra Constitución no prevé remedios como los que conoce la Unión Europea,

${ }^{44}$ Así, radicalmente, entre otros, SANTAMARÍA PASTOR, J. A., Fundamentos..., p. 330: "si... es la norma autonómica la posterior, la consecuencia será la nulidad de ésta, exactamente igual que en virtud del principio de jerarquía". 
es conveniente tenerlo en cuenta para que no salga siempre completamente gratis el incumplimiento del Derecho estatal.

\subsection{Colisión entre norma autonómica y norma estatal poste- rior: inaplicabilidad general, desplazamiento o deroga- ción y nulidad sobrevenida}

Nos ocupamos ahora del supuesto en el que entre la norma autonómica y la estatal posterior hay una contradicción abstracta y general; una contradicción o incompatibilidad igual a la que se requiere entre normas de un mismo ordenamiento para entender que la posterior ha derogado a la anterior; una contradicción tal que en la generalidad de los casos incluidos en la norma autonómica la aplicación de ésta impide la aplicación de la estatal ¿Qué efectos tiene sobre la norma autonómica la estatal posterior? La respuesta es crucial pero controvertida. Expondré primero la respuesta que creo correcta en la más pura ortodoxia. Después, la que se podría estar dispuesto a aceptar: heterodoxa (o de más cuestionable ortodoxia) pero útil. Y por fin la que ha acogido el TC que, como ya se podrá imaginar, es heterodoxa e inconveniente.

a) Desplazamiento general e indefinido de la norma autonómica ¿O derogación?

Toda norma autonómica, aprobada dentro de la competencia de la respectiva Comunidad y sin oponerse a ninguna norma estatal vigente en ese momento (por tanto perfectamente válida y aplicable en su origen), deviene inaplicable e ineficaz en cuanto resulte contraria a cualquier norma posterior aprobada por el Estado en virtud de sus competencias. Dicho de otra forma: la norma estatal posterior contraria a una norma autonómica anterior, dictadas ambas en el ejercicio de sus respectivas competencias, impide desde ese momento la aplicación de ésta. Esto es así por la prevalencia y porque las normas estatales aprobadas en el ejecicio de sus competencias son de aplicación inmediata y, por eso, han de producir con la misma inmediatez la inaplicabilidad de la norma autonómica anterior incompatible con ella ${ }^{45}$; salvo, claro está, que la propia norma estatal disponga otra $\operatorname{cosa}^{46}$.

\footnotetext{
${ }^{45}$ Es lo que sucede en Alemania y en Estados Unidos donde las nuevas normas federales exigen "su aplicabilidad inmediata" y producen con igual inmediatez "la abrogación de las normas que se le opongan". Vid. MUÑOZ MACHADO, S., Derecho público de las Comunidades Autónomas, cit., I. p. 519.

${ }^{46}$ La norma estatal puede voluntariamente renunciar a su aplicabilidad inmediata. Igual que puede establecer largos periodos de vacatio legis, puede también aceptar que durante un tiempo no impedirá la aplicación de normas autonómicas contrarias. A veces esa opción será muy prudente y saludable o hasta necesaria cuando realmente la puesta en aplicación efectiva de la nueva norma estatal requiera de normas autonómicas, para cuya aprobación puede incluso conceder un plazo. Piénsese en una ley estatal que intro-
} 
Según doctrina extendida, no se trata propiamente de una derogación, puesto que se parte de que no hay derogación nada más que entre normas del mismo ordenamiento ${ }^{47}$. En su lugar, en vez de derogación, se habla de desplazamiento de la norma autonómica de suerte que ésta queda vigente aunque inaplicable ${ }^{48}$. Se trata, empero, de un desplazamiento muy peculiar porque no es ocasional para un caso concreto (como sucede en el concurso opositivo de normas) sino de un desplazamiento general $\mathrm{y}$ de efectos indefinidos en el tiempo. O sea, de un desplazamiento muy similar a la derogación; un, digamos, sucedáneo de derogación, una cuasi derogación. Tanto que autores hay que sin recato ni circunloquios hablan simplemente de derogación ${ }^{49}$, y lo cierto es que con tal cambio se ganaría en claridad y en seguridad jurídica ${ }^{50}$.

duzca una gran reforma sanitaria o educativa cuya puesta en práctica requiera de una nueva organización administrativa. Esto no sólo será apropiado para las leyes básicas sino también en casos en los que, aunque toda la legislación haya de ser estatal, la ejecución sea de competencia autonómica. Incluso podría aceptarse o hasta exigirse que las leyes del art. 150.3 CE, por su contenido ("principios") y función (armonizar legislación previa), establezcan un periodo para que las Comunidades Autónomas aprueben la legislación armonizada. Ello al modo en que sucede con las Directivas de armonización. Pero nada de esto obsta a que, por lo común, las leyes estatales sean de aplicación inmediata y, por tanto, impidan inmediatamente la aplicación de las normas autonómicas anteriores incompatibles con ellas.

${ }^{47}$ MUÑOZ MACHADO, S., Tratado..., cit., II, pp. 243-244. Algo distinta es la idea expuesta por DÍEZ-PICAZO, L. M., La derogación de las leyes, Civitas, Madrid, 1990, pp. 128 y ss., según la cual no puede haber derogación entre tipos normativos relacionados competencialmente, lo cual no impediría siempre y por sí sólo la derogación entre normas de distintos ordenamientos en la medida en que se aceptara que algunas veces las competencias coinciden.

${ }^{48}$ Así, GARCÍA DE ENTERRÍA, E., y FERNÁNDEZ, T. R., Curso..., I, cit., p. 387.

${ }^{49}$ En esta línea, PAREJO ALFONSO, L., La prevalencia..., p. 114; FERNÁNDEZ FARRERES, G., "Colisiones normativas y primacía del Derecho estatal...", cit., pp. 537 y ss. y 565; LASAGABASTER HERRARTE, I., Los principios de ..., cit., pp. 148-149; SANTAMARÍA PASTOR, J. A., Fundamentos..., p. 330; DE ESTEBAN, J., y LÓPEZ GUERRA, L., El régimen constitucional español, Labor, Barcelona, 1982, II, p. 397. Es de particular interés la postura de COSCULLUELA MONTANER, L., "El control...", cit., p. 1755, porque, aunque parte de que en general no hay derogación entre normas de distintos ordenamientos sino sólo desplazamiento, sí la admite en el caso de leyes autonómicas de desarrollo incompatibles con las bases posteriores. Así en su trabajo "El control...", cit. p. 1755, sí que admite la derogación. En igual dirección, admite decididamente la derogación implícita RODRIGUEZ PORTUGUÉS, M., "Sobre los efectos...", aunque sólo para los casos de las leyes de desarrollo de las básicas. Quizá habría que repensar ese dogma de que no cabe derogación entre normas de dos ordenamientos cuando uno de éstos es una especie de subsistema dentro del otro, cuando puede hablarse de un ordenamiento general y principal frente a otro particular, del ordenamiento del todo frente al de la parte. Además, desde un punto de vista teórico tampoco parece acertado hablar de desplazamiento cuando no se trata de un "concurso de normas" sino de una "colisión opositiva de normas". Lo cierto es que el art. 31 de la Ley Fundamental de Bonn ("Bundesrecht bricht Landesrecht"), aunque literalmente dice "rompe" o "quiebra", también se traduce así: "El Derecho federal deroga el Derecho de los Estados", sin que ello lleve a rasgarse las vestiduras.

${ }^{50}$ La única diferencia práctica está en que la derogación, conforme al art. 2.2 in fine CG, no permite la reviviscencia de las normas "por la simple derogación" de la ley que las derogó, mientras que este peculiar desplazamiento del que hablamos supondría que, una vez derogada la ley estatal que las dejó inapli- 


\section{b) Inaplicabilidad general más inconstitucionalidad e invalidez so- brevenida}

Aunque parece una forma retorcida de aludir a un fenómeno bastante más simple, acaso pueda decirse que la norma autonómica incompatible con una norma estatal posterior incurre en inconstitucionalidad sobrevenida ${ }^{51}$. Los problemas comienzan cuando a esa expresión se anuda la consecuencia juridica de una invalidez sobrevenida. Nada objetamos en abstracto a la categoría de la invalidez sobrevenida, ni siquiera a su posible aplicación a normas ${ }^{52}$. Pero parece artificiosa para la situación que nos ocupa, igual que lo sería en cualquier caso de derogación por incompatibilidad con una norma posterior. Haciendo la vista gorda, se puede estar dispuesto a aceptar tal invalidez sobrevenida como un efecto añadido al del simple desplazamiento ge-

cables, resurgirían de sus cenizas las normas autonómicas. Por eso no he dicho que se trate de un desplazamiento perpetuo sino "indefinido en el tiempo"; quizás pudiéramos llamarlo, como a la nueva pena de prisión, desplazamiento "perpetuo revisable".

Hay quien ve ventajas en ese eventual resurgimiento de las normas autonómicas desplazadas. Así, GARCÍA LUENGO, J., “El desplazamiento...”, p. 206: cuando el Derecho estatal vuelva a cambiar, no se producirá un vacío pues automáticamente se tendría ya Derecho regional complementario. Por el contrario, critica con agudeza esta situación MUÑOZ MACHADO, S., Tratado..., II, pp. 272-273. Me parece, en efecto, que esa supuesta ventaja práctica es muy inconveniente pues crea problemas de inseguridad jurídica rayanos en lo esotérico con normas indefinidamente vigentes pero inaplicables que vagan en una especie de limbo a la espera de una eventual y remota reencarnación con la que recuperar alguna vez su eficacia. Imagínese el caos que se crearía si, ante los frecuentes vaivenes de la legislación estatal sobre educación, hubiera que deducir las normas autonómicas que, en estado latente o de hibernación durante mucho tiempo, volvieran a reanimarse por su conformidad sobrevenida con el Derecho estatal nuevo. "La noche de los muertos vivientes" sería un juego de niños comparado con este espectáculo de leyes saliendo de sus tumbas. Y resultaría pobre consuelo el que se nos explicara que no estaban muertas sino dormidas. No me parece que esa ventaja compense los inconvenientes. Entre ellos que se anima, entonces, a que las Comunidades Autónomas no modifiquen formalmente su Derecho a la espera de un posible cambio de la legislación estatal. La inseguridad y el desorden alcanzarían el grado de completo desbarajuste. Pero es que, incluso aunque vuelva a cambiar el Derecho estatal, hacer resurgir a las normas autonómicas antiguas resultaría caótico. Entre otras cosas porque, salvo que lo que haga el Estado sea restablecer pura y simplemente la ley antigua, habría que analizar caso por caso y en operación delicadísima qué partes de las antiguas normas autonómicas son realmente conformes con la nueva normativa estatal. Así que, en conclusión, no se perdería nada bueno si, en vez de desplazamiento, hablásemos sin más rodeos de derogación.

${ }^{51}$ Así, dice RODRÍQUEZ PORTUGUÉS, M., "Sobre los efectos...", cit., en nota de p. 200, que "la inconstitucionalidad sobrevenida es un concepto descriptivo, útil por el fenómeno fáctico que quiere describir (unas leyes constitucionales que, por la razón que sea, pasan a estar en contradicción con la Constitución), pero del que no caben derivar efectos jurídicos a prior". En la misma línea, el voto particular a la STC 1/2003 afirmó que estas normas autonómica contrarias a las estatales posteriores incurren en "inconstitucionalidad sobrevenida", pero sin sacar de ello más consecuencia que su desplazamiento y no dar un paso más.

52 Vid. CANO CAMPOS, T., La invalidez sobrevenida de los actos administrativos, Civitas, Madrid, 2004, pp. 61 y ss. 
neral e indefinido (o sea, al del desplazamiento cuasi derogatorio ${ }^{53}$. Y ello por los beneficios que entraña al permitir una declaración terminante y erga omnes sobre la incompatibilidad de la norma autonómica con la posterior estatal, declaración que, si la norma autonómica tiene rango de ley, habrá de hacer el TC. Por eso lo veremos luego, cuando analicemos en el siguiente epígrafe quién puede hacer estas declaraciones. Anticipemos sólo que, esto, desde luego, lo ha aceptado el TC.

c) Inconstitucionalidad e invalidez sobrevenida, pero no desplazamiento

Pero el TC ha dado un paso más, un paso fatal: el de entender que hay inconstitucicionalidad y nulidad sobrevenidas pero no simultáneo desplazamiento. Sobre todo con especial claridad y consumando todos sus efectos en la STC 66/2011. Se enfrentaba con esta situación: la LRBRL en su redacción originaria de 1985 exigía mayoría de dos tercios del pleno para adoptar acuerdos relativos al cambio de capitalidad de los municipios; la Ley canaria de Régimen Local de 1990, de conformidad con aquella ley básica, exigía exactamente lo mismo, o sea, mayoría de dos tercios (en realidad, reproducía el precepto estatal); el año 2003 se modificó la LRBRL que a partir de ese momento exigía sólo para tales acuerdos mayoría absoluta; todos estaban de acuerdo en que esta reforma era realmente básica, o sea, en que el Estado había impuesto esa mayoría absoluta dentro de sus competencias. Ante ello, cualquiera habría dicho que la norma básica estatal de 2003 había desplazado a la canaria de 19904; los más intrépidos habrían osado aventurar que la había derogado. Y, ya con más apuros, los heterodoxos utilitaristas afirmarían que, además, había una inconstitucionalidad y nulidad sobrevenida, lo que, haciendo de tripas corazón, se puede estar dispuesto a admitir. Pero esta STC afirma:

"la modificación de la ley básica estatal no ha determinado ... el desplazamiento o la pérdida de eficacia de la norma autonómica, sino su inconstitucionalidad sobrevenida".

53 No se puede ocultar la contradicción que entraña y, además, esta nulidad acabaría con la remota posibilidad de reviviscencia de las normas autonómicas desplazadas cuando cambie el Derecho estatal pues hay que suponer que si son nulas y así se declara ya no podrán volver a la vida.

54 Téngase en cuenta que con anterioridad ya la STC 33/1993 había declarado que el listado de la LRBRL sobre supuestos en que era necesaria una mayoría cualificada era "cerrado y exhaustivo" y tenía carácter rigurosamente excepcional" de modo que el legislador autonómico no podía establecer más casos en que fuese necesaria aquella mayoría de dos tercios. Vid CARBONELL PORRAS, E., "Artículo 47" en REBOLLO PUIG, M. (Dir.) e IZQUIERDO CARRASCO, M. (Coord.), Comentarios a la Ley Reguladora de las bases del Régimen local, Tirant lo Blanch, Valencia, 2007, pp. 1178 a 1180. 
Increíble pero cierto, aunque haya que leerlo varias veces para superar la perplejidad. O sea, niega el desplazamiento, niega la pérdida de eficacia (o de vigencia y, por ende, la derogación); y, en su lugar, sólo ve la inconstitucionalidad sobrevenida: la adveniza categoría que sólo estábamos dispuestos a aceptar como un compañero extravagante de conveniencia, acaba con los demás y se convierte en protagonista único $^{55}$. Naturalmente que esta inconstitucionalidad sobrevenida también dará lugar a su inaplicación; pero no ya por desplazamiento o derogación, sino por nulidad. Esto tiene graves consecuencias respecto a quién pueda apreciar esta nulidad y, en suma, aplicar la prevalencia de la norma estatal posterior. Ahora lo veremos.

\section{VIII. ¿QUIÉN APLICA LA PREVALENGIA DE LAS NORMAS ESTATALES?}

\subsection{Planteamiento y respuesta general}

La cuestión es ésta: ante cualquier tipo de oposición entre norma estatal y autonómica ¿quién puede aplicar las diversas consecuencias expuestas en el epígrafe anterior para las tres diferentes situaciones descritas?

A este respecto, como ahora se verá, hay oposición entre el TS y el TC. El primero confiere amplísimas y casi ilimitadas posibilidades a todos los jueces y tribunales para aplicar el principio de prevalencia, o sea, para prescindir de las normas autonómicas contrarias a normas estatales. El segundo, cuando se trate de normas autonómicas con rango de ley, excluye por completo a los jueces y tribunales y se arroga la exclusiva ${ }^{56}$. Puestos a elegir, parece preferible la del TS que es más respetuosa con el principio de prevalencia y causa menos problemas. Pero como suele ocurrir in medio consistit virtus o, por decirlo más llanamente, que ni tanto ni tan calvo, que la solución correcta está a medio camino entre esas jurisprudencias del TS y del TG y, en cualquier caso, requiere más matizaciones de las que hacen uno y otro.

La respuesta que entiendo correcta se puede formular así: cualquiera puede (o hasta debe) aplicar las diversas consecuencias del principio de prevalencia con las solas excepciones que derivan de las competencias atribuidas en exclusiva a la jurisdicción contencioso-administrativa y al Tribunal Constitucional. Por tanto, sólo aquélla

${ }^{55}$ Porque, además, el TC parece partir de la idea de que son conceptos excluyentes. Objeta RODRÍGUEZ PORTUGUÉS, M., "Sobre los efectos...", cit., p. 205, que desplazamiento y nulidad sobrevenida "además de ser diferentes, se mueven en planos distintos", el de la validez y el de la eficacia, de modo que no tienen que ser excluyentes.

${ }^{56}$ Vid. COSCULlUELA MONTANER, L., "La reconstrucción del Estado autonómico", El Cronista del Estado social y democrático de Derecho, no 51 (2015), p. 23. 
podrá declarar formalmente la nulidad de un reglamento o acto autonómico por contrario a una norma estatal; y sólo el TC podrá hacer juicios de inconstitucionalidad de las leyes autonómicas conforme al monopolio que se desprende de los arts. 153.a) y 163 CE. Son estas excepciones las que inevitablemente dan a nuestra prevalencia del Derecho estatal menos fuerza e inmediatez que la que tiene la primacía del Derecho de la Unión Europea.

Veamos ahora cómo se concreta esa respuesta general en cada una de las situaciones posibles.

\subsection{Todos pueden y deben inaplicar la norma autonómica desplazada en el caso concreto}

Es obvia y no cuestionable la solución en el supuesto del mero concurso conflictivo de normas, aquél, recuérdese, en que no se oponen en abstracto sino sólo en un caso concreto: la mera aplicación de la norma estatal y la correlativa inaplicación de la autonómica la tendrá que hacer cualquiera que se enfrente con tal concurso de normas; cualquier juez si en el litigio se le plantea; cualquier órgano administrativo al que corresponda tomar una decisión; y hasta cualquier particular que se encuentre en tal tesitura ${ }^{57}$. A este respecto, donde no hay ningún juicio crítico para la norma autonómica, no hay diferencias entre la prevalencia del Derecho estatal sobre el autonómico y la primacía del europeo sobre el nacional.

\subsection{Nulidad de la norma autonómica contraria a la estatal anterior: monopolio del TC si aquélla tiene rango de ley; resistencia del TS}

Más complicada es la solución para los supuestos de norma autonómica aprobada en contradicción con norma estatal anterior; esto es, los casos en los que la consecuencia, como ya vimos, es la nulidad (originaria) de la norma autonómica:

a) Tal nulidad no la pueden apreciar ni las Administraciones ni los particulares que están vinculados por la presunción de validez de leyes, reglamentos y actos administrativos mientras no se declare su nulidad por el procedimiento establecido

\footnotetext{
${ }^{57}$ Para esto no hace falta acudir a ningún juez ni al Tribunal Constitucional, aunque sí puede ocurrir que también éste, en alguno de los procesos de su incumbencia, se enfrente con tal situación en cuyo caso será él, como cualquier operador jurídico, el que tendrá que optar en favor de la norma estatal e inaplicar la autonómica. Salvando esto, de ninguna forma ni nunca es necesaria ni pertinente la intervención del TC puesto que en absoluto se trata de enjuiciar la constitucionalidad de ninguna norma sino sólo de elegir correctamente la aplicable al caso. La situación no es distinta de la que se produce en los conflictos en-
} 
para ello y por quien tenga la competencia ${ }^{58}$. Mientras tanto, tienen que actuar partiendo de que la norma autonómica posterior es válida.

b) Todos los jueces podrán apreciar la nulidad del reglamento autonómico contrario a norma estatal anterior que por ello deberán inaplicar, pero sólo podrán declarar formalmente esa nulidad los de la jurisdicción contencioso-administrativa ${ }^{59}$.

) Si se trata de una ley o norma autonómica con fuerza de ley, sólo podrá apreciar esa nulidad el Tribunal Constitucional. Cualquier otro juez o tribunal deberá plantear cuestión de inconstitucionalidad: si decide por sí mismo la in-

tre dos normas estatales o entre dos normas autonómicas: quien deba actuar o resolver cualquier procedimiento o proceso deberá seleccionar la norma aplicable y excluir otra, aunque sea una ley. Lo único peculiar es que en los supuestos que analizamos deberá hacerlo en virtud del principio de la prevalencia del Derecho estatal mientras que en otros lo hará en función del de especialidad, subsidiariedad o el que sea. Nada de esto, en definitiva, suscita ningún problema ni duda.

${ }^{58}$ Ello supone declaración por un juez o tribunal ordinario o por el TC, según lo que de inmediato se dice en el texto. Pero a ello hay que sumar la posibilidad de que la misma Administración autonómica autora del reglamento acuerde su nulidad mediante revisión de oficio (art. 106.2 LPAC) basada en la vulneración del Derecho estatal.

${ }^{59} \mathrm{Su}$ nulidad podrá ser declarada por los órganos de lo contencioso-administrativo. En ese sentido FERNÁNDEZ FARRERES, G., La contribución..., p. 433. Y tanto en recurso directo como indirecto o, a veces, en cuestión de ilegalidad. No parece que esto requiera de especiales explicaciones: los reglamentos son objeto prototípico de los recursos contencioso-administrativo; la nulidad de los reglamentos entra entre las posibles pretensiones del contencioso-administrativo y entre los posible contenidos de las sentencias; se puede alegar cualquier vicio del reglamento, incluido desde luego éste de su contradicción con una norma estatal anterior; no se trata de reivindicar una competencia... En suma, no se alcanza a imaginar siquiera ningún obstáculo a un proceso contencioso-administrativo contra un reglamento autonómico fundado, sólo o con otros argumentos, en su contradicción con una norma estatal previa.

Y no muy distinta será la situación si se trata de un recurso indirecto contra el reglamento autonómico, esto es, de un recurso contra un acto de aplicación de tal reglamento basado en la nulidad de éste por su contradicción con norma estatal anterior. El Juzgado o Tribunal resolverá apreciando la ilicitud del reglamento y fallando de acuerdo con ello con la única especialidad de que, si no es el competente para declarar su nulidad, planteará después la cuestión de ilegalidad ante el Tribunal contencioso-administrativo que corresponda para que sea éste el que haga tal declaración. No hay en todo esto nada más que aplicación de las reglas generales sobre los contencioso-administrativos contra cualquier reglamento. Además, cualquier juez de cualquier jurisdicción podrá inaplicarlo de acuerdo con el art. 6 LOPJ. Esto es seguro y para nada de esto es necesaria y ni siquiera posible la intervención del TC. No obstante, al margen de ello, podría intervenir el TC en dos casos. Primero, si el Gobierno impugna el reglamento autonómico por la vía del art. 161.2 CE o plantea un conflicto de competencias (aunque no parece éste la vía adecuada para combatir estas normas autonómicas). Y, segundo, si el juez que esté conociendo del asunto decide plantear la cuestión de inconstitucionalidad, pero ello sólo cuando la norma estatal que debe aplicar con prevalencia tenga rango de ley y dude si es constitucional; en concreto, dude si ha sido dictada dentro de las competencias del Estado puesto que ello es premisa necesaria para que pueda aplicar el principio de prevalencia. En ningún otro caso debe ni puede plantear cuestión de inconstitucionalidad. Estos dos casos, por tanto, no desvirtúan lo dicho en el texto y, por tanto, la impertinencia general de intervención del TC. 
constitucionalidad de la norma y la inaplica por ello (aunque no la anule formalmente), incurre en exceso de jurisidicción e incluso en vulneración del derecho fundamental del art. $24 \mathrm{CE}^{60}$.

Lo expuesto es conforme a la doctrina del TC que consideramos correcta (lo criticable es que va mucho más lejos, como de inmediato veremos). Pero la Sala $3^{\text {a }}$ del TS se aparta de lo últimamente expuesto. Se sintetiza su postura en la STS de 25 de septiembre de 2013 (rec. cas. 6557) que cita y reproduce otros pronunciamientos anteriores del mismo Tribunal ${ }^{61}$. Se enfrentaba con una Ley valenciana de 2005 que consideró opuesta a una Ley estatal básica de 1998: ésta imponía repetir el trámite de in-

${ }^{60}$ Así lo dejó ya sentado con claridad la STC 163/1995, que estimó una cuestión de inconstitucionalidad contra una ley andaluza contraria a una ley básica preexistente: excluyó que la regla de la prevalencia del Derecho estatal permitiera a un juzgado o tribunal, sin más, inaplicar aquélla. Concretamente dice su fundamento jurídico 4: “... que los Jueces y Tribunales integrantes del Poder Judicial no pueden pretender una excepción a lo previsto en los arts. 163 y 153.a) CE, así como en el correspondiente precepto estatutario, como consecuencia de un determinado entendimiento de lo previsto, de forma más general y en un diferente contexto constitucional, en el art. 149.3, inciso segundo, in fine, CE". Como en este caso, según hemos dicho, la ley autonómica nació ya vulnerando las bases anteriores, esta STC es correcta. Pero en realidad no hizo esa distinción. Es más, su razonamiento, basado en que se trataba de un "control de constitucionalidad", ya se prestaba al error. Pero, aunque tenía el germen del error, en esta STC no se consumó. Asimismo la idea de que si un juez decide por sí mismo inaplicar la ley autonómica posterior a la estatal prevalente sin plantear cuestión de inconstitucionalidad vulnera el derecho del art. $24 \mathrm{CE}$ se ha aplicado en SSTC 178/2004, 58/2004 y sobre todo 187/2012 y 177/2013. También, más recientemente, en la STC 195/2015. Todas ellas, al no hacer las distinciones necesarias (es decir, al no circunscribir lo que afirman a los casos en que la ley estatal prevalente es anterior a la autonómica) tienen una doctrina errónea o que, por lo menos, induce a error. Pero su solución concreta no es equivocada en tanto que se referían a supuestos en que la ley autonomómica se había aprobado contradiciendo lo establecido en una ley estatal anterior. Por eso resulta desconcertantante el voto particular que formula el Magistrado Xiol a la STC 195/2015. Su argumentación es correcta y concorde en esencia con lo que aquí se viene sosteniendo. Pero parece que es impertinente para el caso que allí se enjuciaba en el que se oponía legislación autonómica aprobada en el año 2004 a ley estatal aprobada en 1998. Sin embargo dice este voto particular: "El objeto de este recurso de amparo plantea, una vez más, el supuesto de una ley autonómica que, dictada al amparo de una competencia de desarrollo, deviene contraria a la normativa estatal básica por una modificación sobrevenida de ésta". Acaso pueda aceptarse este planteamiento porque la norma autonómica en cuestión era un Texto Refundido y si es que su precepto controvertido provenía de una ley autonómica anterior a 1998, extremo que ni siquiera apunta.

${ }^{61}$ Sobre todo, STS de 13 de mayo de 2013 (rec. cas. 3400/2009) y ATS de 30 de abril de 2013. También son precedentes de interés, aunque sin la argumentación completa sobre lo que nos ocupa, las SSTS de 9 de diciembre de 2008 (rec. cas. 7459/2004), 14 de octubre de 2009 (rec. cas. 5988/2005) y 28 de junio de 2012 (rec. cas. 3013/2010). Algunas de ellas con votos particulares de interés. Además, esta postura del TS no está huérfana de apoyo doctrinal. Así, RUBIO LLORENTE, F., El bloque de la constitucionalidad, Civitas, Madrid, 1991, p. 131: "Las leyes autonómicas que regulan materias que han sido también objeto de una ley estatal podrán ser pura y simplemente inaplicadas por el juez ordinario, sin consulta alguna al juez constitucional, en virtud de la cláusula de prevalencia del art. 149.3, asumiendo así, aunque sólo sea con referencia al caso concreto, el control de la ley". Vid. también GARCÍA TORRES, J., "La cláusula de 
formación pública si el plan de urbanismo aprobado inicialmente sufre después modificación sustancial, mientras que para la Ley valenciana bastaba notificárselo a los afectados que ya estuvieran personados. El TS, sin plantear cuestión de inconstitucionalidad, decidió aplicar la ley estatal y resolver conforme a ella, inaplicando sin más las ley autonómica posterior. En su argumentación -con tiento y habilidad para dar apariencia de sometimiento al TC- invoca el principio de prevalencia del art. 149.3 CE y afirma que simplemente se ha procedido a seleccionar la norma aplicable, lo que entra de lleno en su función jurisdiccional. Pero sobre todo hay que realzar esta afirmación: "al seleccionar la norma aplicable al caso, sin incluir ningún juicio de eventual [in]constitucionalidad de normas autonómicas, no excedemos nuestro cometido" ${ }^{62}$. Eso es lo que, en el fondo, podría sustentar la postura del TS.

Si bien se observa, esta jurisprudencia del TS que abiertamente contradice lo que hemos dicho para el caso de que la norma autonómica tenga rango de ley, lleva en sí una carga de profundidad que conduce también a negar lo que hemos afirmado cuando la norma autonómica es meramente reglamentaria: esa misma selección de la norma aplicable la podrían hacer todos los jueces de todas las jurisdicciones y también las Administraciones o hasta los particulares, que sencillamente deben elegir la norma aplicable. Si todo eso se acepta, como está ínsito en esta jurisprudencia del TS, nuestro principio de prevalencia pasaría a tener la potencia del principio de primacía del Derecho de la Unión Europea que tiene como corolario, según dijimos, la inaplicación por todos de cualquier norma nacional, sea cual fuere su rango, contraria a cualquier norma europea.

Es tentador. Creo, sin embargo, que esta forma de proceder choca con el sentido de los arts. 153.a) y 163 CE. No hay sólo, aunque así lo quiera presentar el TS,

prevalencia y el poder judicial", Estudios sobre la Constitución Española. Homenaje al Profesor Eduardo García de Enterría, Civitas, Madrid, 1991, pp. 569 y ss.; y DE LA QUADRA SALCEDO FERNÁNDEZ DEL CASTILLO, T., "Sobre la reconstrucción del Estado autonómico", El Cronista del Estado social y democrático de Derecho, $\mathrm{n}^{\circ} 51$ (2015), p. 78: la invalidez de una ley autonómica posterior a la estatal contraria "puede ser declarada por el TC, con independencia de que los órganos judiciales la desconozcan e inapliquen".

${ }^{62}$ La misma tesis, y respecto a un supuesto prácticamente idéntico, la mantuvo poco después la STS de 27 de febrero de 2014 (rec. cas. 5116/2011). En este caso era la legislación urbanística castellano-manchega de 2004 la que eximía de repetición de la información pública en ciertos casos de modificaciones sustanciales del planeamiento y, por ello, contradecía una Ley estatal anterior, la Ley de Suelo de 1998. Esta STS de 27 de febrero de 2014, citando literalmente la de 23 de septiembre de 2013 y el ATS de 30 de abril de 2013, decide, sin plantear cuestión de inconstitucionalidad contra la ley autonómica, inaplicarla y declarar la nulidad del Plan de Ordenación de Toledo por vulneración de la Ley estatal. Esta STS tiene particular interés porque después fue anulada por la STC 195/2015, a la que ya nos hemos referimos en una nota anterior. 
elección de la norma aplicable e inaplicación de la autonómica. Esta inaplicación se basa en su consideración como inconstitucional, aunque se camufle, aunque no se pronuncie formalmente: se inaplica la ley autonómica porque se la considera incursa en una inconstitucionalidad mediata por contradecir un límite constitucional que tenía cuando se aprobó. Y esto cae dentro del monopolio del TC que no sólo cubre la declaración formal de inconstitucionalidad y nulidad de las leyes sino también cualquier juicio sobre su inconstitucionalidad, aunque sólo sea a los efectos de, por su nulidad, inaplicarla. Si no fuese así, ningún juez tendría nunca que elevar cuestión de inconstitucionalidad: le bastaría no incluir formalmente un juicio de inconstitucionalidad de la ley autonómica (o de otra ley cualquiera) y decir que está sólo eligiendo la norma aplicable para burlar el monopolio del TC.

\subsection{Inaplicación por todos de la norma autonómica contra- ria a la estatal posterior. Negación por el TG}

Si se opta, como aquí hemos defendido, por considerar que la norma autonómica devendrá general e indefinidamente desplazada por la estatal posterior, cualquiera que se enfrente con tal colisión de normas deberá simplemente aplicar la norma estatal que es al mismo tiempo prevalente (superior) y posterior. Y ello tanto sea una norma autonómica reglamentaria o tenga fuerza de ley ${ }^{63}$. No habrá en esa elección de la norma estatal posterior aplicable nada que suponga el enjuiciamiento de una ley autonómica ni de la voluntad del legislador ni atisbo de reproche de inconstitucionalidad ni declaración de ningún género sobre su validez: sólo sobre su aplicabilidad y sólo en función de su contradicción con una norma estatal posterior. Igual que si se tratara de la oposición entre dos leyes estatales o de la que se produzca entre dos leyes autonómicas que se suceden en el tiempo. El hecho de que se produzca entre normas de dos ordenamientos no cambia nada. El que se hable de desplazamiento y no de derogación es intrascendente a este respecto. El hecho de que el conflicto deba resolverse en favor de la ley estatal, que es prevalente, y en detrimento de la autonómica tampoco cambia nada. Y el dato de que sea así en virtud de una regla constitucional -la de la prevalencia del Derecho estatal- también es irrelevante puesto que la Constitución, incluido el principio de prevalencia, es norma de aplicación directa por todos, no sólo por el TC. Así que cualquiera que deba actuar o resolver ante esa norma autonómica contraria a una estatal posterior puede y debe optar sin más por ésta. Y, desde luego, puede hacerlo cualquier juez sin que para ello deba plantear cuestión de inconstitucionalidad ${ }^{64}$. Es más, si sólo este efecto del desplazamiento se ad-

${ }^{63}$ Vid. LASAGABASTER HERRARTE, I., Los principios de..., pp. 149 a 151.

64 Así lo razona MUÑOZ MACHADO, S., Informe..., pp. 138-139, hasta concluir que en estos casos no hay "una evaluación de la validez de las normas en conflicto y por ello no es preciso que el TC se 
mite, los jueces no sólo no deberían sino que no podrían suscitar la cuestión de inconstitucionalidad $^{65}$.

Si se acepta que, además de ese desplazamiento, la norma autonómica adolece de inconstitucionalidad y nulidad sobrevenida -o sea, la tesis heterodoxa y utilitarista de que antes hablábamos- habría que admitir que, junto a la posibilidad de que cualquiera inaplique la norma autonómica, cabe obtener una declaración formal de tal inconstitucionalidad y nulidad. Entonces reaparece la competencia del TC, pero sólo cubre una parte. Si se trata de una norma autonómica reglamentaria, esa declaración de inconstitucionalidad y nulidad sobrevenida podrá hacerla la jurisdicción contenciosoadministrativa; y sólo eventualmente el TC si el reglamento es impugnado por la vía del art. 161.2 $\mathrm{CE}^{66}$. Pero si se trata de una norma autonómica con fuerza de ley, los arts. 153.a) y 163 CE imponen el monopolio del TC: sólo él podrá declarar la nulidad e inconstitucionalidad sobrevenida de la ley autonómica. La consecuencia práctica es

pronuncie preventivamente". Igualmente, entre otros, LEGUINA VILLA, J., "Notas sobre...", cit., pp. 237238. Tras insistir en el monopolio del TC para declarar la inconstitucionalidad de las leyes autonómicas por su contradicción con leyes básicas, al final excepciona abiertamente los casos en que la contradicción se produzca con una norma estatal posterior porque se tratará sólo de una cuestión de "falta de vigencia", no de invalidez; porque la "ley básica posterior ... deroga directamente la ley básica anterior e indirectamente también la ley autonómica...". Así, concluye que "en tal operación ... no hay, como se ve, juicio alguno sobre la validez de las normas en conflicto, sino sólo escrutinio de las normas derogadas, según la regla general del art. 2.2 CC, y elección de la norma vigente y, por tanto, aplicable al caso". Igualmente, entre otros, SÁNGHEZ MORÓN, M., Derecho Administrativo. Parte general, Tecnos, Madrid, 10a ed., 2014, pp. 180 y 325. Está línea también ha contado con valedores en el propio TC, aunque sólo plasmada en votos particulares. El último relevante el de Xiol Rius a la STC 195/2015: tras recordar el principio de prevalencia y de recalcar que "la legislación básica debe prevalecer sobre las leyes autonómicas... aprobadas válidamente en su momento", afirma que esta prevalencia no da lugar a "un supuesto de declaración de nulidad de la norma autonómica cuyo monopolio competa al TC ex art. 163 CE" sino que "es un supuesto de inaplicación en que la normativa autonómica resulta desplazada por criterios de prevalencia que, como labor de interpretación y aplicación de normas en conflicto, puede ser desarrollada con naturalidad por los órganos jurisdiccionales...". Lástima que, como hemos observado antes, este voto parece impertinente para el caso que abordaba la STC 195/2015 y contra la que se formula pues allí no se trataba de una ley estatal posterior a la autonómica sino anterior a ella.

${ }^{65}$ Ello salvo que el juez dude de la constitucionalidad de la ley estatal; sobre todo, que dude si la ley estatal ha respetado la distribución de competencias pues si no fuese así no podrá prevalecer. Lo observa agudamente COSCULLUELA MONTANER, L., "El control de las leyes autonómicas...", cit., p. 1755: “... la derogación de la ley autonómica puede apreciarla el Tribunal contencioso-administrativo directamente, salvo que dudando de la validez de la ley estatal deba plantear previamente la cuestión de constitucionalidad...".

${ }^{66}$ Todo, sin embargo, sometido a los plazos del respectivo recurso que de ordinario se habrán superado ya, sin que se haya planteado su reapertura tras la aprobación posterior de una norma estatal contradictoria. Tal vez podría lograrse tal declaración de nulidad sobrevenida mediante revisión de oficio por la misma Administración autonómica. 
(o sería si es que se aceptara esta construcción) la siguiente: cualquiera puede simplemente inaplicar la ley autonómica; cualquier juez puede inaplicar la ley autonómica pero podría, en vez de ello, elevar cuestión de inconstitucionalidad en cuyo caso el TG pronunciaría formalmente la inconstitucionalidad y nulidad de la ley. Además, claro está, cabría también (si se está en plazo) recurso de inconstitucionalidad contra la ley autonómica que, si prospera, terminaría con igual pronunciamiento de inconstitucionalidad y nulidad sobrevenidas ${ }^{67}$. Ello tendría ventajas: la de permitir al juez en los casos más dudosos someter el juicio al TC; la de permitir un recurso de inconstitucionalidad contra la ley autonómica, si se está en plazo; y la de posibilitar una declaración formal erga omnes sobre la ley autonómica con el aumento de la seguridad jurídica que ello entraña ${ }^{68}$. Esto es conforme con jurisprudencia consolidada del TC que por ello ha venido admitiendo tanto cuestiones de inconstitucionalidad como recursos de inconstitucionalidad frente a leyes autonómicas contrarias a normas estatales posteriores $^{69}$. Todo al igual que en su momento se aceptó que las leyes anteriores a la Constitución y contrarias a ella tenían la doble condición de leyes derogadas y de leyes con inconstitucionalidad y nulidad sobrevenidas, y ello con el efecto útil de permitir, por

\footnotetext{
${ }^{67}$ Vid. MUÑOZ MACHADO, S., Tratado..., II, pp. 272-273.

${ }^{68}$ Vid. MUÑOZ MACHADO, S., Tratado..., II, cit., pp. 243-244; y FERNÁNDEZ FARRERES, G., La contribución..., cit., p. 312.

${ }^{69}$ Creo que la primera vez en que lo hizo fue en STC 27/1987. En un recurso de inconstitucionalidad contra una Ley valenciana de 1983 consideró que ésta, aunque inicialmente correcta, tenía un precepto que resultaba contrario a la LRBRL de 1985 y declaró la "nulidad (del precepto autonómico)... con efectos desde la entrada en vigor de la citada Ley de Bases...". Después, más clara y directamente lo hizo en la STC 1/2003: recurso de inconstitucionalidad contra ley extremeña de la función pública que cuando se aprobó era conforme con la legislación básica pero que, por modificación posterior de ésta, devino disconforme con ella. Estimó el recurso por considerar que esa disconformidad sobrevenida suponía su nulidad sobrevenida. También responde a este esquema la STC 162/2009 al resolver cuestión de inconstitucionalidad contra una ley aragonesa de 1999 contraria a ley estatal de 2003. Igualmente lo ha aplicado en la STC 106/2014 al resolver el recurso de inconstitucionalidad contra la ley cántabra de 2013 que prohíbe el fracking por ser contraria a ley estatal básica aprobada meses después, que lo permite: estima el recurso porque la ley autonómica "resulta incompatible con la legislación básica estatal sobrevenida, lo que determina la inconstitucionalidad y consiguiente nulidad...". Estas SSTC no son erróneas en sí mismas en la medida en que cabe aceptar la nulidad sobrevenida, siempre que no se excluya el simultáneo desplazamiento de la norma autonómica y, por tanto, su inaplicación por todos. Lo criticable es que no lo aclarasen y que, por su forma de razonar y por su olvido del principio de prevalencia, incubaron el mal que la STC 66/2011 consumó. Fue esto lo que ya detectó el certero voto particular formulado por tres Magistrados a la STC 1/2003, que ya reclamaba la solución pura en virtud del principio de prevalencia. También cuenta con un voto particular la STC 106/2014, pero de éste nada útil para lo aquí expuesto puede salir: no cambia el planteamiento y no acude de ninguna forma a la prevalencia, sino a la competencia (sacando incluso a relucir la idea del título competencial prevalente). Se sitúa de lleno en la línea aquí repudiada. Algo más que el germen del error hay en la STC 166/2014: ante una ley autonómica que devino contraria a una ley estatal posterior, estimó la cuestión de inconstitucionalidad planteada. Hasta aquí nada que objetar. Pero
} 
una parte, que cualquiera pudiera inaplicarlas y, por otra, que pudieran ser objeto de una declaración erga omnes de nulidad por el $\mathrm{TC}^{70}$. Por las mismas razones y buscando la misma utilidad cabe aceptarlo aquí ${ }^{71}$.

Pero, como ya anunciamos, el TG ha optado por considerar que no hay ni desplazamiento ni derogación sino sólo inconstitucionalidad y nulidad sobrevenidas. Con esa premisa, la solución para lo que ahora nos ocupa es esta otra: sólo él, el propio TC, puede resolver estas colisiones frontales entre norma autonómica con rango de ley y norma estatal posterior ${ }^{72}$. Esta solución aparece acabadamente en la ya aludida STC 66/2011. Procede ahora completar el supuesto al que se enfrentó y la solución que le dio. Recordemos que se trataba de la colisión entre una ley canaria de 1990 incompatible con una ley estatal básica de 2003. La Administración aplicó sin más la ley estatal de 2003; contra ello recurrió una asociación de vecinos que precisamente se basaba en la ley canaria; la jurisdicción contencioso-administrativa desestimó el recurso por considerar que la ley canaria era contraria a la estatal posterior y que, por tanto, ésta era aplicable y aquélla había devenido inaplicable. Y contra estas senten-

en su FJ 6 va tan lejos como la 66/2011: no se produce "el desplazamiento de la ley autonómica por la posterior legislación básica estatal opuesta a aquélla, sino su inconstitucionalidad sobrevenida y la necesidad de que dicha consecuencia se declare precisamente por este Tribunal, previo planteamiento de la correspondiente cuestión de inconstitucionalidad".

70 Todo ello, no sin controversia como revela el voto particular de Rubio Llorente a la STC 4/1981, de 2 de febrero, cuya argumentación, por cierto, podría también servir para criticar la idea de la invalidez sobrevenida de las normas autonómicas contrarias a normas estatales posteriores. Sobre esa jurisprudencia de la derogación y de la nulidad sobrevenida de las leyes preconstitucionales son interesantes CANO CAMPOS, T., La invalidez sobrevenida ..., cit., pp. 62-63; y DÍEZ-PICAZO, L. M., La derogación de las leyes, cit., pp. 310 y ss. No es eso lo que aquí nos ocupa. Nos basta poner de manifiesto que con esa acumulación de consecuencias (derogación y nulidad sobrevenida) lo que en el fondo se buscaba era permitir el control de los jueces y el del TG. Por eso ALEGRE ÁVILA, J. M., "La invalidez sobrevenida de los actos jurídicos: inconstitucionalidad sobrevenida e invalidez sobrevenida de los actos administrativos", Revista Andaluza de Administración Pública, no 83 (2012), p. 492, dice que "el sintagma inconstitucionalidad sobrevenida no es ... sino un mero nomen que apela a una cuestión jurisdiccional...". Lo mismo es lo que sucede aquí si se predica de las normas autonómicas contrarias a normas estatales posteriores que están derogadas (o desplazadas) y que al mismo tiempo tienen inconstitucionalidad sobrevenida.

${ }^{71}$ Pero aunque se esté dispuesto a aceptarlo por su utilidad práctica conste que se pueden alzar contra él muchas razones teóricas y que, de hecho, con mayor rigor, lo negaron categóricamente los votos particulares a las SSTC 1/2003 y 66/2011, como luego se verá. Y en la doctrina lo rechaza radicalmente GARCÍA LUENGO, J., "El desplazamiento...”, sobre todo, pp. 194 a 197, hasta concluir en p. 209 que este concepto está "huérfano de cualquier lógica jurídica".

${ }^{72}$ Se supone, aunque no lo dice el TC, que si la norma autonómica en colisión con la estatal posterior es reglamentaria no se da el monopolio del TC. Se tratará también -cabe deducir- de un reglamento devenido inconstitucional y nulo. Pero eso lo podrá declarar la jurisdicción contencioso-administrativa y apreciar cualquier otro juez que, en virtud del art. 6 LOPJ, podrá simplemente inaplicarlo, ahora no por considerarlo desplazado o derogado, sino por considerarlo "contrario a la Constitución, a la ley o al principio 
cias la asociación vecinal pidió amparo por vulneración del art. 24 CE. Pues bien, la STC otorgó el amparo con este razonamiento: como no hay desplazamiento, sino inconstitucionalidad, y como se trata de una ley, sólo el TC puede decidir su contradicción con la norma estatal posterior. Por tanto, el Juzgado y el Tribunal de lo Contencioso debieron plantear la cuestión de inconstitucionalidad. No hacerlo supone -exactamente igual que si estuviera ante una ley autonómica posterior a la estatal- "menoscabar la posición ordinamental de la ley en nuestro Derecho y soslayar su singular régimen de control"; también exceso de jurisdicción; dictar una sentencia no fundada en Derecho; y, por fin, violación de derecho fundamental del art. $24 \mathrm{CE}^{73}$.

Los diversos elementos de esta argumentación se han ido gestando a lo largo del tiempo en la jurisprudencia del TC: algunos ya tenían en potencia la solución errónea de esta STC 66/201 $1^{74}$. Además se han vuelto a reiterar en SSTC posteriores ${ }^{75}$. Pero es la STC 66/2011 la que lleva esta fundamentación hasta sus últimas consecuencias.

de jerarquía normativa", por decirlo con las mismas palabras del art. 6 LOPJ. En ese sentido, COSCULLUELA MONTANER, L., "El control...", cit., p. 1745.

${ }^{73}$ Ya se puede imaginar lo sucedido en ese caso concreto después de esta STC 66/2011: el asunto volvió al Juzgado tinerfeño que planteó la cuestión de inconstitucionalidad resuelta por STC 159/2012, de 17 de septiembre, que declaró la inconstitucionalidad y nulidad de aquél precepto canario. Es de suponer, aunque no nos consta, que finalmente el Juzgado de Tenerife dictó sentencia en el mismo sentido de la primera

${ }^{74}$ Así, el progresivo abandono del principio de prevalencia y la admisión de recursos de inconstitucionalidad y de cuestiones de inconstitucionalidad contra las leyes autonómicas incompatibles con normas estatales posteriores sin la más mínima alusión a que también cabía la simple inaplicación de la ley autonómica aparecen ya en las SSTC 27/1987, 163/1995, 173/2002, 1/2003, 58/2004 y 162/2009. Incluso así, podía seguir pensándose que cualquiera podía inaplicar esa ley autonómica incompatible con la estatal posterior y que el TC no lo declaraba porque no era lo que se le planteaba en el caso. O sea, cabía sostener que el TC simplemente acogía la vía heterodoxa de sumar inaplicación e inconstitucionalidad sobrevenida y que, por tanto, admitía su propia competencia sin perjuicio de la mera inaplicación por todos.

${ }^{75}$ Concretamente SSTC 187/2012, 177/2013, 106/2014, 166/2014 y 195/2015: en todas ellas se discurre en la misma línea que la STC 11/2011. Pero con diferencias sobresalientes. Tres de ellas (las SSTC 187/2012, 177/2013 y 195/2015) se ocupan de casos en que la ley estatal era anterior de modo que, como observa certeramente RODRÍGUEZ PORTUGUÉS, M., "Sobre los efectos...”, cit., pp. 205-206, nota 10, es correcto que el TC acepte su competencia y excluya la de los jueces y tribunales ordinarios. En el caso de la SSTC 106/2014, se trata de una ley autonómica originariamente válida (la ya aludida Ley de Cantabria de 2013 que prohibía el fracking) que después devino incompatible con una ley estatal posterior. Pero lo que resuelve es un recurso de inconstitucionalidad y no hay inconveniente en admitirlo y estimarlo, si se acepta la solución heterodoxa pero útil de acumular desplazamiento y nulidad sobrevenida: el TC puede resolver el recurso y declarar la inconstitucionalidad y nulidad sobrevenidas de la ley autonómica sin que ello niegue que cualquier juez o tribunal pueda simplemente inaplicarla por darla por desplazada. Y en el caso de la STC 166/2014 se trataba de resolver una cuestión de inconstitucionalidad contra la ley autonó- 
Esta solución no tiene, que sepamos, parangón en el Derecho comparado. Desde luego, claro está, sólo puede existir cuando hay un control concentrado de la constitucionalidad de las leyes. Por tanto, no es siquiera imaginable en los Estados Unidos. Tampoco es ni remotamente similar a lo que se acepta para hacer valer la primacía del Derecho de la Unión Europea respecto a los nacionales que impone que cualquier juez deba inaplicar toda norma -incluidas las que tengan rango de ley y hasta constitucional- contraria a aquél. Pero es que ni en Alemania -con un TC que, como el nuestro, tiene el monopolio de la declaración de inconstitucionalidad de las leyes- rige nada similar sino que se acepta que los jueces y tribunales ordinarios pueden por su propia autoridad y en ejercicio de su normal función jurisdiccional inaplicar la norma de uno de los Land incompatible con el Derecho Federal posterior ${ }^{76}$.

Los comentaristas de esta STC 66/2011, todos críticos, han puesto de relieve tanto los defectos de su razonamiento y solución, como sus lamentables consecuencias ${ }^{77}$. Por lo que a lo primero se refiere, ante todo esta jurisprudencia -y especialmente la STC 66/2011- prescinde del principio de prevalencia, como bien observó el impecable voto particular del Magistrado Delgado Barrio ${ }^{78}$ y la doctrina ${ }^{79}$. Tanto que, a fuer de exactos, no es que el TC se haya arrogado la exclusividad de la aplicación del principio de prevalencia frente a leyes autonómicas; es más bien que lo ignora por completo y que lo que debería resolverse conforme a la prevalencia lo plantea y resuelve como un problema de incompetencia (de una absurda incompetencia sobrevenida) ${ }^{80}$; es la apreciación de esa incompetencia y la declaración de su consecuencia, la nulidad, lo que

mica devenida contraria a la estatal posterior, cuestión que no hay inconveniente en admitir y estimar sin perjuicio de aceptar que el juez que la planteó también pudo simplemente inaplicar la ley autonómica. Así que, insistamos, sólo en la STG 66/2011 se consuma plenamente y se aplica la conclusión inadmisible.

${ }^{76}$ Ello, por cierto, pese a que la literalidad del art. 100.1 in fine de la Ley Federal de Bonn pudiera dar pábulo a otra solución cuando dispone que ese monopolio del TC federal "rige también cuando se trate ... de la incompatibilidad de una ley de un Land con una ley federal". Se ha entendido que esto sólo rige cuando esa norma federal sea anterior a la ley del Land, no cuando sea posterior pues en este último caso "no se está cuestionando la autoridad del Legislador estatal sino fijando el Derecho vigente". Lo explica así GARCÍA LUENGO, J., "El desplazamiento...”, p. 197, con cita de jurisprudencia y doctrina alemanas.

77 GARCÍA LUENGO, J., "El desplazamiento...”, pp. 191 a 203 y 209; RODRÍGUEZ PORTUGUÉS, M., "Sobre los efectos de la legislación...", cit., pp. 205 a 213; RUÍZ LÓPEZ, M. A., "La cláusula de prevalencia...", cit., sobre todo pp. 160 y ss.

${ }^{78}$ Literalmente afirmaba, con todo acierto y rotundidad, que la solución de la STC 66/2011 "prescinde del mandato constitucional de prevalencia" y que "el abandono del principio de prevalencia es, ante todo y sobre todo, una inaplicación de la Constitución”. A este respecto no razona más ni hacía falta porque, en efecto, la solución de la sentencia es flagrantemente contraria al principio de prevalencia.

${ }^{79}$ RODRÍGUEZ PORTUGUÉS, M., "Sobre los efectos de la legislación...”, cit., pp. 205-206.

${ }^{80}$ Por ello, con razón, MUÑOZ MACHADO, S., Informe..., p. 136, presenta esta jurisprudencia como consecuencia de plantear estos problemas como problemas de incompetencia. 
el TC se arroga en exclusiva. Además parte de la premisa insostenible, como ya se explicó, de que en estos casos hay inconstitucionalidad y nulidad pero no desplazamiento ni derogación; y, siendo tal premisa errónea, lo es su conclusión. También hurta a los jueces su función jurisdiccional ${ }^{81}$ al desorbitar el ámbito y el sentido del monopolio del $\mathrm{TC}^{82}$ que, como es obvio, se estableció para que los jueces ordinarios no pudieran enjuiciar la constitucionalidad de las decisiones de los legisladores, no para que no puedan decidir que una ley posterior debe aplicarse en vez de la anterior contraria. Porque no es ya que se prescinda de la prevalencia del Derecho estatal sino hasta del elemental principio de que la ley posterior impide la aplicación de la anterior incompatible con ella.

En cuanto a lo segundo, a sus consecuencias, se ha dicho que son negativas para los litigantes del pleito concreto -que se alargará con el planteamiento de una cuestión de inconstitucionalidad- hasta el punto de poder constituir una vulneración del derecho a obtener justicia en un plazo razonable ${ }^{83}$. Lo son, explican también los autores, para el propio funcionamiento del sistema porque supone que la real y efectiva entrada en vigor de la nueva norma estatal se podrá posponer hasta un remoto pronunciamiento del $\mathrm{TC}^{84}$. Mientras tanto tendrá una fuerza potencial, pero en letargo. Y es que si los jueces han de plantear cuestión de inconstitucionalidad, todos los demás, incluidas las Administraciones, que no pueden plantear tal cuestión ante el $\mathrm{TC}_{\text {¿qué deben }}$ hacer? ¿qué debería hacer un empresario ante una norma estatal que liberalice por completo los horarios comerciales o las rebajas entretanto las leyes autonómicas anteriores no se modifiquen para adaptarse a la nueva legislación estatal? ¿y qué deberán hacer las Administraciones encargadas de hacer cumplir esa regulación comercial? ¿ignorar la liberalización hasta que el legislador autonómico apruebe una nueva ley

${ }^{81}$ Por ello objeta GARCíA LUENGO, J., "El desplazamiento...”, p. 195, que "los Jueces y Tribunales ordinarios tienen el monopolio constitucional de la jurisdicción" que comprende "la labor de juzgar la vigencia de la norma y su aplicabilidad a cada caso concreto", monopolio que esta jurisprudencia constitucional aniquila.

${ }^{82}$ MUÑOZ MACHADO, S., Informe..., cit. pp. 136-137.

${ }^{83}$ RODRÍGUEZ PORTUGUÉS, M., "Sobre los efectos de la legislación...”, cit., p. 208. GARCíA LUENGO, J., "El desplazamiento...”, pp. 203-204. También el voto particular de Delgado Barrio hablaba de "graves e inconvenientes consecuencias prácticas" y lo justificaba poniendo de relieve que se daba lugar a "un complejo peregrinaje jurisdiccional -de ida al Juzgado de lo Contencioso-Administrativo, de vuelta al Tribunal Constitucional y otra vez de ida a dicho Juzgado- que ha de conducir a que se dicte una nueva sentencia con el mismo fallo que ahora anulamos". Sólo cabe objetar que, además de este absurdo peregrinaje judicial y del retraso para los litigantes y para la justicia, hay efectos aún más nocivos para el funcionamiento de todo el sistema y para las posibilidades del legislador estatal, consecuencias desastrosas contra las que el voto particular no alertó.

${ }^{84}$ RODRÍGUEZ PORTUGUÉS, M., “Sobre los efectos de la legislación...”, cit., pp. 208-209 
adaptada? Y, al margen de ese ejemplo ¿es que hay que seguir aplicando como si nada las leyes autonómicas urbanísticas claramente incompatibles con la Ley 8/2013 de Rehabilitación, Regeneración y Renovación Urbanas? ¿o todas las leyes autonómicas que han devenido incompatibles con la LRBRL tras la reforma introducida por la Ley 27/2013? ¿o las que resulten contrarias a las nuevas Leyes de Procedimiento Administrativo Común o de Régimen Jurídico del Sector Público? Los ejemplos pueden multiplicarse. La respuesta implícita en este jurisprudencia es que, en efecto, habrá que seguir aplicando la ley autonómica a la que, sorprendentemente, se le da una preferencia transitoria, todo hasta provocar algún proceso en el que un juez plantee la cuestión de inconstitucionalidad y permita al TC pronunciarse para, tras ello, deshacer todo lo hecho. A la postre, por tanto, no sólo se sobrecarga de trabajo al TC, que a duras penas y con retraso puede con lo que realmente le corresponde, sino que se multiplica absurdamente la litigiosidad obligando a todos a suscitar procesos para que los jueces eleven cuestión de inconstitucionalidad.

Lo peor es que, en el fondo, esta jurisprudencia acaba hasta con la aplicabilidad directa de las normas estatales. Y, sobre todo, nótese que la capacidad del legislador estatal para alterar efectivamente el Derecho, afrontar situaciones coyunturales o imponer nuevas políticas queda muy mermada. Tal vez conseguirá imponer efectivamente sus reformas cuando ya se hayan aprobado las siguientes. Y, entonces, vuelta a empezar. En cualquier caso, da un arma a las autoridades autonómicas que quisieran obstruir la efectiva vigencia de las leyes estatales que puede conducir a situaciones aberrantes. $\mathrm{Y}$ en un hipotético escenario de deslealtad institucional generalizada, esta jurisprudencia será fatal.

\section{REGAPITULAGIÓN Y PROPUESTA}

No todo lo que aquí se ha contado es la historía de lo que pudo ser y no fue. No es la historia virtual de nuestro principio de prevalencia. Pero sí hemos ido viendo su potencial y cómo ha sido desperdiciado. Ni respetándolo y aplicándolo en toda la medida en que aquí se ha defendido podrá equiparse en fuerza y virtualidad al principio de primacía de la Unión Europea. Pero es el caso, como creo haber demostrado, que por una suma de desviaciones y errores, se han malogrado las muchas posibilidades que sí tenía y que se desprenden de la misma Constitución. Todo hasta llegar a la situación paradójica, por no decir ridícula, de que nuestro principio de prevalencia, el de un Estado con una Constitución que lo proclama, no es ya casi nada, al tiempo que el de primacía de la Unión -que no es un Estado y que en ningún Tratado lo proclamaba- es de fuerza irresistible. Urge recuperar el principio de prevalencia, restablecerlo en toda su dimensión y operatividad. 
Desde luego, se puede y se debe hacer aunque no se modifique la Constitución. Es más, todo lo aquí defendido es lo que, como también se ha ido viendo, sostuvo la buena doctrina, acaso con ocasionales desfallecimientos por contaminación. Pero si una reforma de la Constitución se emprendiera, debería incluir sin ninguna duda una nueva formulación del principio. Así, por lo pronto, estaría más justificado y sería más fácil romper con la situación creada, acabar con la inercia y superar la jurisprudencia que poco a poco lo ha ido dilapidando, carcomiendo hasta dejarlo reducido a polvo, ceniza, nada. Sería, además, una oportunidad de redactarlo más correctamente en un precepto dedicado sólo a él ${ }^{85}$.

No se trata de hacer aquí una propuesta concreta. Cualquiera, inspirada en los referentes que ofrecen la Constitución de los Estados Unidos o la Ley Fundamental de Bonn o la misma Unión Europea -aunque en este caso no hay un concreto precepto que lo plasme-, serviría. Bastaría con decir que el Derecho del Estado aprobado en virtud de sus competencias (o, tal vez, "aprobado conforme a la Constitución", que es más amplio y más parecido a lo que dice la Constitución americana) prevalece (o, quizá, mejor, "prima", para huir hasta de los mismos términos, escapar más fácilmente de los errores anteriores y evocar el modelo de la Unión Europea) sobre el de las Comunidades Autónomas y todos están obligados a observarlo (de nuevo, al modo de la Constitución de EEUU). Con esa o parecida redacción, lo que en otros preceptos se establezca sobre el monopolio del TC hará el resto y compatibilizará esta prevalencia o primacía o superioridad del Derecho estatal con nuestro sistema concentrado de control de constitucionalidad de las leyes. Por otro lado, no debería suscitar reticencias en tanto que sólo se trata de recoger lo mismo que en Constituciones de Estados Federales sólidos o en la Unión Europea, que, se supone, no es propiamente ni eso.

Un precepto de este género sería mucho más útil e importante que mejorar la distribución de competencias y mitigaría sus defectos e insuficiencias que, por mucho que se perfeccione, inevitablemente tendrá. También paliaría ciertas carencias de nuestra Constitución como la inexistencia de un deber expreso de acomodación del Derecho autómico al estatal y de instrumentos de coerción para hacerlo cumplir al modo en que

\footnotetext{
85 No resultará difícil mejorar su actual consagración en el art. 149.3 CE que, forzoso es reconocerlo, no es modélica. Por lo pronto, aparece en una oración subordinada, pese a ser un principio clave, sin que su contenido guarde ninguna relación con la oración principal. Súmese a lo anterior que lo circunscribe a "caso de conflicto" y a los supuestos en que no haya "exclusiva competencia" de las Comunidades Autónomas, todo lo cual sobra y crea confusión. Y ello en un precepto, ese art. 149.3, abigarrado en el que, además, aparece, en primer lugar, la posibilidad de que las Comunidades Autónomas asuman en sus Estatutos las competencias sobre las materias no atribuidas expresamente al Estado por la Constitución y, al final, la supletoriedad del Derecho estatal respecto al de las Comunidades Autónomas. Así, suma a los defectos de su inspirador (el art. 21 de la Constitución Española de 1931), otros cuantos. Con independencia
} 
conocen, no ya los Estados Federales, sino hasta la Unión Europea ${ }^{86}$. Carencias que, sumadas a la eliminación de un verdadero principio de prevalencia, colocan al Estado, frente a las Comunidades Autónomas, en una posición de postración frustrante en cualquier sistema que pretenda ser tal.

En conclusión, con o sin reforma constitucional, la búsqueda de la prevalencia perdida hasta rescatarla del triste destino que se le ha asignado es misión indeclinable, prioritaria y urgente. La reforma de la Constitución sería una oportunidad para hacer más fácil esa tarea que en todo caso hay que emprender.

\section{ADENDA. LA REGTIFICACIÓN PARCIAL DEL TRIBUNAL CONSTITUGIONAL EN SUS SENTENGIAS 102, $116 \mathrm{Y}$ $127 / 2016$}

1- Actualizado hasta abril de 2016 el anterior estudio y entregado ya a la imprenta, se han producido las SSTC 102, 116 y 127/2016, de 25 de mayo, 20 de junio y 7 de julio. Aun con el comedimiento propio que aconseja estar en fase de corrección de una galerada, es necesario dar aquí noticia de la novedad que esas sentencias entrañan.

de que quizá esta redacción nefasta sirva de atenuante para los responsables del abandono del principio de prevalencia, queda claro que, en efecto, vale la pena en una eventual reforma de la Constitución intentar una proclamación más clara.

${ }^{86}$ Repárese que no hay en nuestra Constitución nada equiparable al art. 4.3 TUE: “... Los Estados miembros adoptarán todas las medidas generales o particulares apropiadas para asegurar el cumplimiento de las obligaciones derivadas de los Tratados o resultantes de los actos de las instituciones de la Unión. Los Estados miembros ayudarán a la Unión en el cumplimiento de su misión y se abstendrán de toda medida que pueda poner en peligro la consecución de los objetivos de la Unión". Tampoco hay nada similar al recurso por incumplimiento con posibilidad a la larga de imposición de multas coercitivas y "sumas a tanto alzado" (art. 260 TFUE). Por no haber, ni siquiera hay un deber de adaptar o derogar formalmente las normas autonómias incompatibles con las estatales posteriores. Naturalmente la situación es por completo diferente en el Derecho europeo y el Tribunal de Justicia sí entiende que existe un deber de los Estados de purgar sus ordenamientos, incluso derogando formalmente sus normas contrarias a las comunitarias (SSTJ Comisión c. Italia de 15 de octubre de 1986 y Provincia de Bolzano de 11 de junio de 1989). Vid. MUÑOZ MACHADO, S., Tratado..., II, p. 276. Sólo alguna vez el TC ha apuntado tímidamente en esa dirección. Por ejemplo, en la STC 27/1987, que declaraba la inconstitucionalidad sobrevenida de una ley autonómica por su contradicción con una ley estatal posterior, se leía: “... debiendo proceder, en su caso, las Cortes Valencianas a adaptar las correspondientes previsiones legales a lo dispuesto en esta Ley" estatal. Aun más timoratamente la STC 158/2011 dice que la modificación de las bases comporta para las normas autonómicas "su necesaria adaptación a la nueva legislación básica". Pero más que un madato parece un pío consejo. Y ahora, con su jurisprudencia que prescinde de la prevalencia y que niega la mera inaplicación de la ley autonómica contraria al Derecho estatal hasta que el propio TC la declare nula, un pío consejo sólo para Comunidades Autónomas muy leales. 
Las tres sentencias se refieren sólo a uno de los tipos de conflictos entre normas autonómicas y estatales de los que hemos hablado: al que se produce entre leyes autonómicas anteriores que devienen contrarias a normas estatales posteriores.

2- Al margen quedan los otros géneros de conflictos normativos que hemos analizado. En concreto, el de la ley autonómica contraria a normas estatales anteriores; es decir, el de la ley autonómica que desde el mismo momento de su aprobación era ya contraria a la legislación estatal. A este respecto no hay novedad alguna. Al contrario, las seis sentencias dictadas últimamente a este respecto (SSTC 92, 93, 98, 113, 114 y 115/2016) mantienen la solución consolidada: la ley autonómica es nula (con nulidad originaria) por inconstitucionalidad indirecta; y tal nulidad sólo podrá declararla el TC de suerte que los jueces tendrán que plantear la cuestión de inconstitucionalidad. Las seis se ocupan del mismo caso que la STC 195/2015, de 21 de septiembre, el de la aprobación del Plan de Ordenación de Toledo, del que ya hemos dado cuenta. La contradicción analizada se producía entre una ley urbanística castellano-manchega de 2004 y la ley estatal del Suelo de 1998: ésta exigía la repetición del trámite de información pública siempre que hubiera modificaciones sustanciales mientras que la autonómica posterior eximía de tal trámite en ciertas condiciones y supuestos que precisamente se habían dado en la tramitación del Plan de Toledo. Los Tribunales Contencioso-Administrativos simplemente inaplicaron la ley autonómica sin plantear cuestión de inconstitucionalidad (exactamente igual que ya había hecho la STS de 25 de septiembre de 2013 respecto a la legislación urbanística valenciana, según hemos explicado). E, interpuestos recursos de amparo, las seis SSTC citadas, igual que la 195/2015, los estiman y declaran violados los derechos a la tutela judicial efectiva y a un proceso con todas las garantías por no haberse suscitado la cuestión de inconstitucionalidad. Esta solución es, como hemos venido defendiendo, correcta. Cosa distinta es que en su fundamentación se deslicen ocasionalmente argumentos erróneos y excesivos que llevarían a extender la misma solución a supuestos distintos en los que no procede plantear la cuestión de inconstitucionalidad.

3- Pero volvamos al tipo de conflictos en el que sí hay novedades, el de las leyes autonómicas que cuando se aprobaron no vulneraban ninguna norma del Estado pero que, después, por la modificación de la legislación estatal, resultan contrarias a ésta. Las tres SSTC 102, 116 y 127/2016 se refieren a los mismos hechos: dos municipios coruñeses (Oza dos Ríos y Cesuras) tramitaron un procedimiento de fusión voluntaria. En Cesuras 7 concejales votaron a favor de la fusión y 4 lo hicieron en contra. Según la LRBRL, desde su modificación en 2003, para esta clase de acuerdos plenarios bastaba la mayoría absoluta del número legal de miembros de la Corporación sin ningún otro requisito. En cambio, la Ley gallega de Administración Local de 1997, además de esa mayoría absoluta, exigía que votasen a favor dos tercios del número de he- 
cho. Lo hacía así porque reproducía la redacción inicial, la de 1985, de la LRBRL. Aunque en el caso no se alcanzaron esos dos tercios, la Xunta, aplicando la redacción vigente de la LRBRL y marginado por sí misma la de la ley autonómica, dio por conseguida la mayoría necesaria y aprobó la fusión. Interpusieron tres diferentes recursos contencioso-administrativos contra tal aprobación autonómica los concejales discrepantes de Cesuras y de Oza. Y en los tres procesos contencioso-administrativos el TSJ de Galicia, de acuerdo con la jurisprudencia anterior del TC (en especial, con la STC 66/2011), se creyó obligado a plantear cuestiones de inconstitucionalidad que son las resueltas por las SSTC 102, 116 y 127/2016, todas ellas plenamente coincidentes hasta el punto de que, en realidad, las dos últimas transcriben los fundamentos de la primera. Como se ve, la fortuna ha querido que se tratase de un caso prácticamente idéntico al de la STC 66/2011: así se hace más evidente el cambio de jurisprudencia. Como es la STC 102/2016 la que marca la pauta, sigámosla para exponer la novedosa solución.

4- La rectificación es formal y expresa. Así, en su FJ 2, esta STC 102/2016, tras recordar su doctrina anterior, dice: "Este Tribunal considera, sin embargo, que según los argumentos que se exponen a continuación, debe apartarse de la doctrina antes indicada...".

En esencia, la rectificación consiste en permitir que cualquiera inaplique la ley autonómica devenida contraria a la legislación estatal sin necesidad de pronunciamiento del TC.

Pero para calibrar exactamente el cambio es necesario enfrentar diversas cuestiones ¿En qué fundamenta el TG su rectificación? ¿Qué ámbito material tiene? ¿Se produce desplazamiento e inconstitucionalidad o sólo desplazamiento? ¿Se puede y debe resolver sin acudir al TC o sigue cabiendo que los jueces planteen cuestión de inconstitucionalidad?

5- Por lo que se refiere al fundamento, el TC apunta varios argumentos: la imposibilidad de que ciertos sujetos planteen cuestión de inconstitucionalidad; lo que sucede con reglamentos ejecutivos que devienen contrarios a leyes posteriores; y lo que sucede con las leyes nacionales que resultan contrarias a normas europeas posteriores. Además, en la misma dirección hay unas afirmaciones muy valiosas en sí mismas: “... el legislador autonómico (...) debe acomodarse a la modificación de la legislación estatal básica..."; la Comunidad Autónoma tiene un "deber de inmediata acomodación de su legislación de desarrollo a la nueva legislación básica”. Y tras ello aparece el principio de prevalencia:

"En fin, es la solución que se corresponde con lo dispuesto en el art. 149.3 CE que atribuye a las normas del Estado prevalencia...". 
Por lo pronto, ya es novedad de bulto que se hable expresamente de la prevalencia. También es relevante que se invoque respecto a la relación bases/desarrollo para la que algunos habían negado que tal principio fuese de aplicación. Pero es que, además, se hacen varias explicaciones sobre la prevalencia que, a la postre, se convierte en protagonista:

* Se afirma que está destinada, "no a fijar las competencias del Estado y de las Comunidades Autónomas, sino a solucionar los conflictos que puedan producirse en aplicación de las normas respectivas...", lo que es correcto.

* Se dice que de esta regla de la prevalencia son "destinatarios los aplicadores del Derecho sin distinción", lo que cual es acertado y relevante.

* Se dice asimismo que la prevalencia "proporciona una herramienta útil para que las relaciones entre el ordenamiento jurídico estatal y los de las Comunidades Autónomas puedan desarrollarse con fluidez...". Tras el olvido constante del principio de prevalencia, el que se afirme que es "una herramienta útil" es un paso que debe celebrarse.

6- El ámbito material de la nueva solución ésta está limitado por varias vías.

En primer lugar, se circunscribe a las relaciones entre norma básica y norma autonómica de desarrollo, dictadas ambas en virtud del mismo título competencial. Y ello porque se considera que sólo en tal caso opera el principio de prevalencia. Se excluyen del ámbito de la prevalencia los conflictos entre normas estatales y autonómicas dictadas en virtud de títulos diferentes:

“... en los supuestos en que con apoyo en títulos competenciales distintos, Comunidad Autónoma y Estado aprueban productos normativos incompatibles, el conflicto planteado se resuelve sin traer a colación el art. 149.3 CE, en favor del título competencial considerado más específico...".

No comparto esta afirmación. Por supuesto que, antes de aplicar la prevalencia, debe comprobarse que las dos normas se han dictado con competencia. También puede aceptarse que para resolver lo anterior se tenga en cuenta a veces y entre otros criterios el de la mayor especialidad de un título competencia. Pero, una vez hecho así, puede suceder -y sucede con normalidad- que las dos normas se hayan dictado dentro de las respectivas competencias. Y si ello ocurre no hay ninguna razón para que no despliegue sus efectos la prevalencia del Derecho estatal. La afirmación recién transcrita del TG supone una reducción injustificada y errónea del significado y ámbito del 
principio de prevalencia del Derecho estatal que, además, es amplia y resulta muy inconveniente. Para el caso concreto que se resolvía no se dejan sentir los efectos perniciosos de tal restricción, pero se evidenciarán con frecuencia en otros muchos supuestos. Lo cierto es que, excluida la prevalencia de la relación entre normas estatales y autonómicas aprobadas en diversas materias, en esos mismos casos queda excluida por completa la nueva solución y se mantiene, como antes, la necesaria intervención del TC.

Pero es que, además, en segundo lugar, la STC 102/2016 introduce otra restricción a la nueva solución: la confina a las llamadas leges repetitae. De hecho, hace consideraciones específicas sobre ellas en los FJ 5 y 6 para explicar que no hay siempre inconstitucionalidad cuando las leyes autonómicas de desarrollo reproduzcan normas estatales básicas, que a veces ello sólo merecerá, si acaso, "reproches de técnica legislativa" sin perjuicio del "carácter superfluo de la legislación reproductora". Con ese punto de partida, sólo admite su nueva solución para tales casos. De hecho, comienza aclarando que cambia su jurisprudencia para "un caso como el que da origen a la presente cuestión de inconstitucionalidad en que la legislación autonómica no ha hecho sino reproducir la legislación básica, y ésta se modifica después en un sentido incompatible con aquella legislación autonómica" (FJ 2). Y después explica que el supuesto analizado es peculiar porque se trata de un precepto básico que se introdujo en la ley autonómica de desarrollo "por puro mimetismo". Parece, por tanto, que sólo en tales hipótesis (la de las normas de desarrollo que reproducen normas básicas) admite que no se plantee la cuestión de inconstitucionalidad. Ningún fundamento se ofrece para esta segunda restricción que sólo parece obedecer al hecho de que eso era lo que se presentaba en el caso concreto y quizá al miedo a la inseguridad que produce que cualquiera puede por su cuenta inaplicar leyes autonómicas: sólo en el caso de las leges repitatae la operación es tan simple que no hay riesgo de inseguridad. Pero lo cierto es que, le guste o no al TC y aunque en efecto esto provoque inseguridad, todos los sujetos (sobre todo las Administraciones) que se encuentran con normas estatales y autonómicas contradictorias tienen que elegir una e inaplicar otra sin que, salvo los jueces, puedan plantear la cuestión de ilegalidad. Así que esta restricción del TC no soluciona el problema sino que deja a todos, salvo a los jueces, ante un callejón sin salida.

Tal vez pudiera verse otra restricción a la nueva solución en su argumentación basada en que sólo los jueces pueden plantear la cuestión de inconstitucionalidad:

"El operador jurídico primario (...) tiene necesariamente que operar con la técnica del desplazamiento de una de las leyes en conflicto y no tiene legitimación para suscitar cuestión de inconstitucionalidad...". 
En el caso enjuiciado, ese "operador jurídico primario" era una Administración. Pero, además de que ello es muy frecuente, en otros supuestos el operador jurídico primario será un sujeto privado que tampoco puede plantear la cuestión de inconstitucionalidad: así, cuando se trate de normas de Derecho privado e incluso de Derecho Administrativo (incluido el Tributario y el de la Seguridad Social) cuando, como es normalísimo, quien primero ha de observarlas es un particular. Así que esta supuesta restricción de la excepción tiene ínfimas consecuencias prácticas. Como máximo, podrían quedar excluidas las normas procesales que primeramente deban ser aplicadas por jueces que sí pueden elevar la cuestión de inconstitucionalidad. Así que el argumento de la falta de legitimación para suscitar cuestión de inconstitucionalidad no añade una restricción adicional a la nueva solución y es sólo un argumento complementario que, como dice la misma sentencia, "pone de manifiesto de un modo más patente las consecuencias inconvenientes a que conduce la aplicación de nuestra doctrina" (FJ 3).

Sea como fuere, lo cierto es que no hay un abandono completo de la jurisprudencia anterior sino sólo una rectificación parcial. Se mantiene aquélla con una excepción para las leyes autonómicas de desarrollo que reproducen preceptos básicos después modificados ${ }^{87}$. Una excepción que, aunque significativa, si se interpreta estrictamente, tendrá un ámbito reducido.

7- Pero, exactamente ¿qué sucede en esos supuestos en que se admite la excepción? Lo aborda la STC en su FJ 6. Tal y como hemos hecho antes, distingamos entre los efectos materiales (desplazamiento o derogación o nulidad) y la cuestión de quién puede aplicarlos (todos, los jueces o el TC).

Respecto a lo primero el TC habla claramente de inaplicación y desplazamiento de la ley autonómica. Y rechaza la derogación. Lo sorprendente es que rechaza también la inconstitucionalidad y nulidad sobrevenidas:

"Es este uno de los casos en los que la aplicación del principio de prevalencia del derecho estatal no determina la derogación de la norma autonómica ni ha de conducir a su nulidad por inconstitucionalidad sobrevenida, sino que puede resolverse (...) inaplicando la ley autonómica por considerar prevalente la posterior legislación básica estatal".

${ }^{87}$ Coinciden así estas tres SSTC con la rectificación propuesta por GONZÁLEZ SANFIEL, A. M., "Desplazamiento versus inconstitucionalidad sobrevenida (La lucha encubierta entre la jurisdicción ordinaria y el Tribunal Constitucional)", en BAÑO LEÓN, J. M. (Coord.), Memorial para la reforma del Estado. Estudios en homenaje al profesor Santiago Muñoz Machado, CEPC, Madrid, 2016, II, p. 1638, estudio valioso que por razones temporales no pudo tenerse en cuenta en la redacción inicial de este artículo. 
Que rechace la derogación obedece a doctrina relativamente extendida por más que aquí antes hayamos subrayado que este desplazamiento es muy similar a una derogación. Lo asombroso es que también niega la nulidad por inconstitucionalidad sobrevenida. En teoría, me parece correcta esa negación, pero supone un apartamiento de la precedente doctrina del TC que no era necesario y que quizá case mal con su mantenimiento general: si en los otros casos el TC va a seguir sosteniendo que la norma estatal posterior incompatible con una ley autonómica anterior produce la inconstitucionalidad y nulidad sobrevenida de ésta, no se entiende muy bien que en este caso no se produzca ese efecto. En este contexto, habría sido más razonable afirmar la nulidad por inconstitucionalidad sobrevenida, aunque simultánea al desplazamiento.

8- En cuando a los sujetos que pueden realizar la valoración de la contradicción entre norma estatal y autonómica y aplicar la prevalencia, la respuesta de la STC 102/2016 es corolario de lo que acabamos de señalar. Obvio es que si hay desplazamiento la "cuestión de inconstitucionalidad ante este Tribunal (...) resulta (...) innecesaria". Pero, ¿además de innecesaria es improcedente? En efecto, eso afirma ahora el TC: como sólo hay desplazamiento y no inconstitucionalidad y nulidad sobrevenidas, no puede intervenir el TC y, en suma, las cuestiones de inconstitucionalidad planteadas se declaran inadmisibles. Se completa en el FJ 7 con un argumento discutible o sólo tautológico: como la ley autonómica "no resulta aplicable al caso (...) debemos declarar la inadmisibilidad" de la cuestión. O sea, queda desterrada la solución heterodoxa que aquí estábamos dispuestos a aceptar por la utilidad que tenía conseguir una declaración erga omnes sobre la incompatibilidad de la ley autonómica con el Derecho estatal subsiguiente. De nuevo hay que decir que en principio es una opción razonable, incluso la más pura y conforme a la prevalencia. Lo dudoso es que encaje bien con el mantenimiento de la jurisprudencia anterior en otros ámbitos. Ahora va a haber unos casos en los que es imprescindible plantear la cuestión de inconstitucionalidad so pena de incurrir en violación del derecho a la tutela judicial efectiva; y otro (el de las leyes de desarrollo que repitan preceptos básicos) en los que la cuestión de inconstitucionalidad ni siquiera cabe. No habrá supuestos en que el juez pueda optar entre solucionar el problema por sí mismo (mediante la prevalencia y la inaplicación) y plantear la cuestión ante el TC: en un caso deberá optar por aquella y en los demás por ésta.

9- Por tanto, el TC rectifica sólo en parte: no abandona por completo su jurisprudencia anterior. Sólo introduce una excepción muy reducida. Pero también muy significativa. Abre una brecha que debe ampliarse. Y espero y auguro que así se hará porque hay en estas sentencias elementos capaces de propiciar una rectificación más amplia y radical, la que supondrá rescatar de su olvido y revitalizar el capital principio de la prevalencia del Derecho estatal. Más aun: la situación, con su distinción artificiosa entre unos casos y otros, ha quedado en un punto de equilibrio inestable que 
no podrá mantenerse por mucho tiempo y la lógica y la Constitución impondrán que el equilibrio estable se alcance con la plena asunción de la prevalencia del Derecho estatal y todas sus consecuencias.

10- Si las tres SSTC son iguales, también lo son en esencia los votos particulares. Lo llamativo y preocupante es que ha ido aumentando el número de Magistrados discrepantes. En la primera, STC 102/2016 -que es del Pleno porque acordó recabar para sí el conocimiento del asunto-, de los once Magistrados sólo Asúa Batarrita emitió voto particular al que nadie se adhirió. En la segunda, STC 116/2016 -que es de Sala-, de los cinco Magistrados que la componían, entre los que no estaba Asúa, dos emitieron voto particular que consiste sólo en asumir el que aquélla había formulado a la sentencia anterior. En la tercera, STC 127/2016 -otra vez del Pleno que asumió la competencia a propuesta de la Sala-, de los once Magistrados cinco suscribieron el voto particular que formuló Asúa. O sea, que la sentencia salió adelante por seis votos contra cinco. Si esto sigue así, no habrá una cuarta sentencia en la misma acertada dirección. Esperemos que no siga el contagio y el TC consolide y amplíe la línea de estas sentencias. Por lo demás, de esos votos particulares sólo nos interesa ahora destacar que son perfectamente conscientes de la relevancia del cambio y de que se trata en definitiva de una "nueva interpretación de la cláusula de prevalencia". También observan que es difícil que el cambio jurisprudencial se quede en los estrictos límites a los que por ahora se le somete y que "se deja abierta la puerta a la aplicación de este cambio doctrinal a otros supuestos". Ojalá que en esto acierten y que, en efecto, el TC abra amplia y definitivamente esa puerta hasta recuperar el principio de prevalencia en su plenitud. 